\title{
18. CENOZOIC RADIOLARIA FROM THE EASTERN TROPICAL ATLANTIC, DSDP LEG 41
}

\author{
David A. Johnson, Woods Hole Oceanographic Institution, Woods Hole, Massachusetts
}

\section{INTRODUCTION}

Radiolarians were identified at each of the five sites drilled on Leg 41 . The localities of these sites are as follows:

\begin{tabular}{|c|c|c|c|c|c|}
\hline Site & Latitude & Longitude & $\begin{array}{l}\text { Water } \\
\text { Depth } \\
\text { (m) }\end{array}$ & $\begin{array}{l}\text { Total } \\
\text { Pene- } \\
\text { tration } \\
\text { (m) }\end{array}$ & $\begin{array}{l}\text { General } \\
\text { Location }\end{array}$ \\
\hline 366 & $05^{\circ} 40^{\prime} .7 \mathrm{~N}$ & $19^{\circ} 51^{\prime} .1 \mathrm{~W}$ & 2853 & 850.5 & $\begin{array}{l}\text { Sierra Leone } \\
\text { Rise }\end{array}$ \\
\hline 367 & $12^{\circ} 29^{\prime} .2 \mathrm{~N}$ & $20^{\circ} 02^{\prime} .8 \mathrm{~W}$ & 4748 & 1153 & $\begin{array}{l}\text { Cape Verde } \\
\text { Basin }\end{array}$ \\
\hline 368 & $17^{\circ} 30^{\prime} .4 \mathrm{~N}$ & $21^{\circ} 21^{\prime}$.W & 3366 & 984.5 & $\begin{array}{l}\text { Cape Verde } \\
\text { Rise }\end{array}$ \\
\hline 369 & $26^{\circ} 35^{\prime} .5 \mathrm{~N}$ & $14^{\circ} 59^{\prime} .9 \mathrm{~W}$ & 1752 & 488.5 & $\begin{array}{l}\text { Cap Bojador, } \\
\text { Continental } \\
\text { Rise }\end{array}$ \\
\hline 370 & $32^{\circ} 50^{\prime} .2 \mathrm{~N}$ & $10^{\circ} 46^{\prime} .6 \mathrm{~W}$ & 4214 & 1176.5 & $\begin{array}{l}\text { Abyssal } \\
\text { Plain off } \\
\text { Morocco }\end{array}$ \\
\hline
\end{tabular}

Two of these sites (366 and 369 ) recovered substantial thicknesses of radiolarian-bearing sediment within continuously cored intervals. Site 366 is of particular biostratigraphic significance in that a virtually complete Cenozoic section was recovered with wellpreserved calcareous microfossils throughout the section, and well-preserved radiolaria in the middle Eocene to middle Miocene interval. Site 369 is noteworthy in having recovered a thick Oligocene section (thickness $\sim 180$ meters) containing wellpreserved radiolaria of Mediterranean affinities, and several cores of Maestrichtian age with unusually wellpreserved assemblages (see Foreman, this volume). Sites 367,368 , and 370 contain identifiable radiolaria only in scattered intervals; extensive downslope reworking and mixing of assemblages at Site 370 precluded precise age assignments for much of the Cenozoic material.

\section{SCOPE OF INVESTIGATION AND PRESENTATION OF RESULTS}

After shipboard preparation and analysis of all corecatcher samples, each core within which radiolarians had been identified was sampled at intervals of approximately one sample per $150-\mathrm{cm}$ section. In the intervals where core-catcher examination revealed no radiolarians, only one or two additional samples per core were prepared. Microscope slides of coarse

'Contribution No. 3822 of the Woods Hole Oceanographic Institution. fraction preparations were prepared according to standard techniques described by Riedel (1957) and Riedel and Sanfilippo (in press).

All samples were examined and described in a preliminary way for the purpose of this report. The primary objective was to determine the occurrences at Leg 41 sites of radiolarian taxa previously recognized to be stratigraphically useful in tropical and subtropical assemblages. These data are discussed and summarized in tabular form in the section "Radiolarians at Each Site". These tables present species occurrences within the continuously cored intervals at those sites where radiolarians are sufficiently common and well preserved to allow age determination. The lists include all stratigraphically useful species which were identified, but other useful taxa may be present in some of the samples. This is particularly true for the middle and upper Eocene sediments at Site 366, in which the radiolarian assemblages are especially diverse. The Oligocene through middle Miocene section at Hole 369A (Cores 1 through 32) contains taxa which bear close affinities to the Mediterranean assemblages described previously by Sanfilippo et al. (1973). A more extensive taxonomic and biostratigraphic investigation of this material from Hole $369 \mathrm{~A}$ is continuing, and will be presented in a subsequent publication.

Most of the stratigraphic intervals which contain radiolarians also contain calcareous microfossils. Consequently we are able to provide approximate correlations between some of the radiolarian zonal boundaries and the standard nannoplankton and foraminiferal zonations for the eastern tropical Atlantic region. These correlations are presented and discussed in the Biostratigraphic Synthesis (this volume).

In the discussion which follows and in the tabulations, only the Cenozoic radiolarian occurrences are considered. Mesozoic assemblages are discussed in a separate chapter by Helen P. Foreman. The names of most radiolarian taxa have been abbreviated; their full and correct form is given in the List of Species at the end of this report.

An appendix to this report, prepared by Helen P. Foreman, discusses and illustrates some of the radiolarian taxa identified in porcellanite samples from the early Paleogene section cored at Site 368 .

\section{CENOZOIC RADIOLARIAN ZONATION}

Extensive investigations of sediments cored on earlier legs of the Deep Sea Drilling Project have led to the construction of a low-latitude radiolarian zonation for most of the Cenozoic Era. The zonation scheme which will be followed in this report incorporates the additional refinements recently proposed by Riedel and 
Sanfilippo (1974) for subdividing the former Calocycletta virginis Zone of lower Miocene age. The zonal boundaries and ranges of taxa for the upper Paleocene to lower Eocene are described by Sanfilippo and Riedel (1973) and Foreman (1973); the zonation for the middle to upper Eocene is that of Riedel and Sanfilippo (1970), as modified by Foreman (1973); the zonation used for the Oligocene through Pliocene is that of Riedel and Sanfilippo (1971), with subsequent modifications (Riedel and Sanfilippo, 1974). Attempts to subdivide the Quaternary sediments from Leg 41 into radiolarian zones (e.g., Nigrini, 1971) were not successful.

The following table lists the Cenozoic radiolarian zones used in this study, along with the definitions of the zonal boundaries, following the recent modifications proposed by Riedel and Sanfilippo (1974). The zones are arranged in order from oldest to youngest beginning with the Paleocene:

\section{Paleocene}

\section{Bekoma bidartensis Zone}

Base: First morphotypic appearance of Bekoma bidartensis.

Eocene

\section{Buryella clinata Zone}

Base: First evolutionary appearance of Buryella clinata from Pterocodon (?) anteclinata.

\section{Phormocyrtis striata striata Zone}

Base: First morphotypic appearance of Theocorys anaclasta.

Theocotyle cryptocephala cryptocephala Zone

Base: First evolutionary appearance of Theocotyle cryptocephala cryptocephala from Theocotyle cryptocephala nigriniae.

Theocampe mongolfieri Zone

Base: First morphotypic appearance of Theocampe mongolfieri.

Thyrsocyrtis triacantha Zone

Base: First morphotypic appearance of Eusyringium lagena.

Podocyrtis ampla Zone

Base: First evolutionary appearance of Podocyrtis ampla from Podocyrtis phyxis.

\section{Podocyrtis mitra Zone}

First evolutionary appearance of Podocyrtis mitra from Podocyrtis sinuosa.

Podocyrtis chalara Zone

Base: First evolutionary appearance of Podocyrtis chalara from Podocyrtis mitra.

Podocyrtis goetheana Zone

Base: First morphotypic appearance of Podocyrtis goetheana.
Thyrsocyrtis bromia Zone

Base: First morphotypic appearance of Carpocanistrum azyx.

\section{Oligocene}

Theocyrtis tuberosa Zone

Base: First evolutionary appearance of Lithocyclia angustum from Lithocyclia aristotelis.

\section{Dorcadospyris ateuchus Zone}

Base: First evolutionary appearance of Dorcadospyris ateuchus from Dorcadospyris triceros.

Lychnocanoma elongata Zone (synonymous with Lychnocanium bipes Zone)

Base: First morphotypic appearance of Lychnocanoma elongata.

\section{Miocene}

Cyrtocapsella tetrapera Zone

Base: First morphotypic appearance of Cyrtocapsella tetrapera.

Stichocorys delmontensis Zone

Base: Last morphotypic appearance of Theocyrtis annosa.

Stichocorys wolffii Zone

Base: First morphotypic apperance of Stichocorys wolffii.

\section{Calocycletta costata Zone}

Base: First morphotypic appearance of Calocycletta costata.

\section{Dorcadospyris alata Zone}

Base: First evolutionary appearance of Dorcadospyris alata.

Cannartus (?) petterssoni Zone

Base: First morphotypic appearance of Cannartus (?) petterssoni.

\section{Ommatartus antepenultimus Zone}

Base: First evolutionary appearance of Ommatartus hughesi.

\section{Ommatartus penultimus Zone}

Base: Last morphotypic appearance of Ommatartus hughesi.

\section{Stichocorys peregrina Zone}

Base: First evolutionary appearance of Stichocorys peregrina from Stichocorys delmontensis.

\section{Pliocene}

Spongaster pentas Zone

Base: First evolutionary appearance of Spongaster pentas from Spongaster berminghami. 


\section{Pterocanium prismatium Zone}

Base: Last morphotypic appearance of Stichocorys peregrina.

\section{Quaternary}

\section{Unzoned}

Base: Last occurrence of Pterocanium prismatium.

\section{RADIOLARIANS AT EACH SITE}

In this section, the information on occurrences of Cenozoic radiolarians is summarized in Table 1A, 1B, $1 \mathrm{C}, 2,3 \mathrm{~A}, 3 \mathrm{~B}$, and 4 for those sites at which significant sequences of radiolarian-bearing sediments were cored (Sites 366/366A; 368; and 369/369A). Radiolarian occurrences at the remaining sites $(367,370)$ are described in the text.

The relative abundance of radiolarians in each sample is indicated qualitatively in the tables as "very abundant" (A), "common (C), "few" (F), "rare" (R), or "very rare" $(+)$. In Table 4 a dot indicates one specimen. Preservation of the specimens is indicated as "excellent" (E), "good" (G), "moderate" $(\mathrm{M})$, or "poor" (P). In the columns showing occurrences of individual taxa, these same relative abundance terms are used to indicate the proportion that a given taxon constitutes of the total radiolarian assemblage. A dash (-) indicates that the taxon was searched for but was not found. An asterisk (*) indicates possible reworking or down-hole contamination.

\section{Site 366/366A}

The continuously cored stratigraphic interval at this site represents a virtually complete Cenozoic section, and is the only such section recovered to date in the tropical Atlantic by DSDP. Calcareous microfossils are sufficiently well preserved to allow zonal age determinations throughout the entire 841-meter section; radiolaria are present within the upper Pleistocene (depth $=0$ to 16 meters) and within the middle Miocene to middle Eocene (depth $=148$ to 622 meters).

\section{Pleistocene}

Cores 1 and 2 contain rare to common specimens of moderately well preserved radiolaria of Pleistocene age. Diagnostic taxa include Lamprocyrtis haysi, Ommatartus tetrathalamus, Theocorythium trachelium, Pterocanium praetextum, Spongaster tetras, Amphirhopalum ypsilon, Lithopera bacca, Axoprunum angelinum, Anthocyrtidium angulare, Eucyrtidium acuminatum, Lamprocyclas maritalis, Pterocanium trilobum, and Theocorythium vetulum. The presence of A. angelinum and A. angulare in Samples 366-1-5, 25-27 $\mathrm{cm}$, through $366-2$, CC, suggest an age within Nigrini's (1971) Zone 4, or greater than 0.9 m.y. according to Johnson and Knoll (1975). There is no indication of reworked Tertiary material in any of the Pleistocene samples examined.

The base of the Pleistocene was not determined since the Pleistocene material below Samples 366-2, CC, and
366A-2, CC, was devoid of radiolarians. Calcareous microfossil assemblages indicate that the Pleistocene/Pliocene boundary is within Core 366A-4, at a subbottom depth of approximately 30 meters.

\section{Miocene (see Table 1A)}

A relatively thick section of middle and lower Miocene age at Site 366A recovered common and generally well-preserved radiolarian assemblages. Table 1A summarizes the distribution of diagnostic taxa in samples examined from the interval between the $D$. alata Zone (Sample 366A-16, CC; depth $=148 \mathrm{~m}$ ) and the base of the L. elongata Zone (Sample 366A-29-5, $56-58 \mathrm{~cm}$; depth $=270 \mathrm{~m}$ ). All zonal boundaries were reliably located between pairs of samples examined except for the base of the L. elongata Zone, which lies within the interval of poorly preserved radiolarian assemblages between Samples 366A-29-5, 56-58 cm, and $366 \mathrm{~A}-30-5,52-54 \mathrm{~cm}$.

A comparison between the stratigraphic ranges of taxa from Site 366 and those from the tropical Pacific and Indian oceans is included in the discussion section of this report.

\section{Oligocene (see Table 1B)}

A thick stratigraphic section of Oligocene age at Site $366 / 366 \mathrm{~A}$ recovered radiolarian assemblages of variable abundance and preservation. Table 1B summarizes the distribution of diagnostic taxa in samples examined from the $D$. ateuchus Zone and $T$. tuberosa Zone (Samples 366A-30-5, 52-54 cm, through $366-9-2,62-64 \mathrm{~cm}$; depth $=279$ to 406 meters). Diversity in these samples is low and preservation is generally moderate to poor. The base of the $D$. ateuchus Zone can be identified with good reliability within Core 366A-37. However, the base of the T. tuberosa Zone is difficult to determine because of the virtual absence of Lithocyclia angustum within the Oligocene section. The base of the $T$. tuberosa Zone probably lies within Core $366-9$, on the basis of the relatively abrupt disappearance of Lithocyclia aristotelis and several species of Theocampe above sample 366-9, CC (see Table $1 \mathrm{~B}$ and $1 \mathrm{C}$ ). This determination is consistent with the placement of the Eocene/Oligocene boundary according to nannofossil and foraminiferal biostratigraphic studies of these samples.

\section{Eocene (see Table 1C)}

Radiolaria of sufficient abundance to allow zonal age determination are present in the upper and middle Eocene sections cored at Site 366.

Table 1C summarizes the distribution of some of the diagnostic forms in the samples which were examined. Radiolarian preservation is generally good in the upper Eocene $T$. bromia Zone, and becomes generally poorer with increasing age in the middle Eocene material. Diversity is generally high in all samples, although poor preservation commonly precluded the identification of many taxa of potential stratigraphic value, particularly within samples of middle Eocene age. Nevertheless, sufficient diagnostic species were present in most 
TABLE 1A

Miocene Radiolarians at Hole 366A

\begin{tabular}{|c|c|c|c|c|c|c|c|c|c|c|c|c|c|c|c|c|c|c|c|c|c|c|c|c|c|}
\hline $\begin{array}{l}\text { Radiolarian } \\
\text { Zones }\end{array}$ & $\begin{array}{c}\text { Samples } \\
\text { (Intervals in cm) }\end{array}$ & & 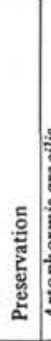 & 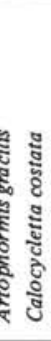 & & & 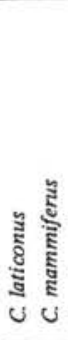 & 胥 & 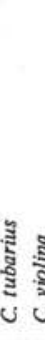 & 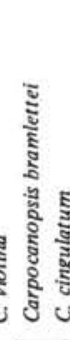 & 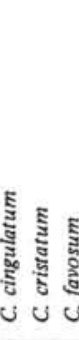 & 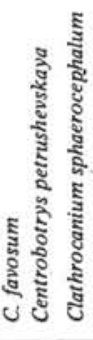 & 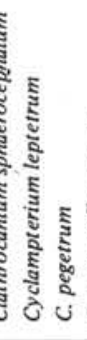 & 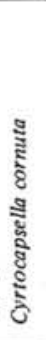 & 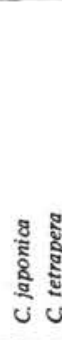 & 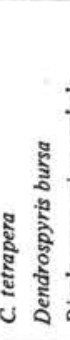 & 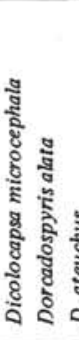 & & 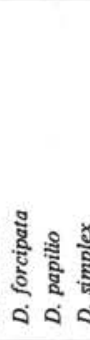 & 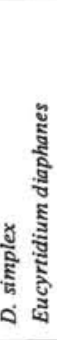 & 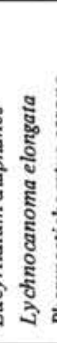 & 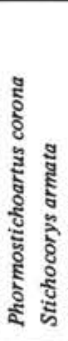 & 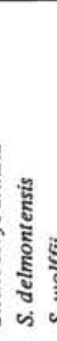 & 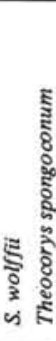 & 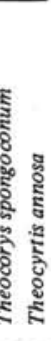 \\
\hline \multirow{7}{*}{$\begin{array}{l}\text { Dorcadospyris } \\
\quad \text { alata }\end{array}$} & $366 \mathrm{~A}-16, \mathrm{CC}$ & & M & $\mathrm{F}$ & & & & & & & & & & & & & F & & & & & & $\mathbf{R}$ & & \\
\hline & $366 \mathrm{~A}-17-1,88-90$ & & M & $\mathrm{R}$ & & $\mathrm{R}$ & & & & & & & & & & & $\mathrm{R}$ & & & & & & F & & \\
\hline & $366 \mathrm{~A}-17-2,67-69$ & C & M & $\mathrm{F}$ & & C & F & & & & & & & & & & c & & & & & & c & & \\
\hline & $366 \mathrm{~A}-17-3,65-67$ & $\mathrm{~F}$ & $\mathrm{M}$ & $\mathrm{F}$ & & $F$ & & & & & & & & & & & $\mathrm{R}$ & & & & & & F & & \\
\hline & $366 \mathrm{~A}-17-4,35-37$ & $\mathrm{~F}$ & $\mathrm{M}$ & $\mathrm{F}$ & & $\mathrm{F}$ & & & & & & & & & & & $\mathrm{F}$ & - & & & & & $\mathrm{F}$ & & \\
\hline & $366 \mathrm{~A}-17-5,25-27$ & $\mathrm{R}$ & M & $\mathrm{R}$ & & $\mathrm{R}$ & + & & - - & & & & & - & & & $\mathrm{R}$ & - & & & & & & - & \\
\hline & $366 \mathrm{~A}-17-6,95-97$ & $\mathrm{~F}$ & M & F & & $\mathrm{F}$ & & & - & & & & & - & & & $\mathrm{R}$ & - & & & & & $\mathrm{R}$ & - & \\
\hline \multirow{4}{*}{$\begin{array}{l}\text { Calocycletta } \\
\text { costata }\end{array}$} & $366 \mathrm{~A}-17, \mathrm{CC}$ & C & G & $\mathrm{R}$ & & C & $\mathbf{R}$ & & - $R$ & & & & & - & & & - & $\mathrm{F}$ & + & & & & $\mathrm{R}-$ & - & \\
\hline & $366 \mathrm{~A}-18-1,65-67$ & $\mathrm{C}$ & G & $\mathrm{F}$ & & c & & & $-R$ & & $F$ & & & $=$ & & & - & $\mathrm{F}$ & & & & & $\mathrm{FH}$ & $\mathbf{R}$ & \\
\hline & $366 \mathrm{~A}-18-2,65-67$ & $\mathrm{c}$ & G & c & & $\mathrm{C}$ & & & - $R$ & R F & $F$ & & & $\mathbf{R}$ & & & - & $\mathrm{F}$ & & & & & C 1 & $\mathrm{~F}$ & \\
\hline & $\begin{array}{l}366 \mathrm{~A}-18-3,65-67 \\
366 \mathrm{~A}-18-4,65-67\end{array}$ & C & G & $\mathrm{R}$ & & C & & & R F & & c - & & & $\mathbf{R}$ & & & - & $\mathrm{F}$ & R & & & & $\mathrm{F} \mathrm{F}$ & $R$ & \\
\hline \multirow{6}{*}{$\begin{array}{l}\text { Stichocorys } \\
\text { wolffii }\end{array}$} & $366 \mathrm{~A}-18-5,65-67$ & C & G & - & & C & F & & R F & $\mathrm{R}$ & R - & & & $\mathbf{R}$ & & & & $\mathrm{R}$ & & & & & C $\mathrm{F}$ & $\mathbf{R}$ & \\
\hline & $366 \mathrm{~A}-18-6,65-67$ & c & $\mathrm{G}$ & - & & c & & & R R & & $F=$ & & & $\mathrm{R}$ & & & & $\mathrm{F}$ & & $\mathrm{F}$ & & & C 1 & $\mathrm{~F}$ & \\
\hline & $366 \mathrm{~A}-18, \mathrm{CC}$ & C & M & - & & C & & & $F R$ & R & $R \quad R$ & & & $\mathrm{R}$ & & & & c & & $\mathrm{F}$ & & & $\mathrm{C}$ & R & \\
\hline & $366 \mathrm{~A} \cdot 20-1,125-127$ & C & G & - & & C & & & C R & & $\mathbf{R}$ & & & $\mathrm{R}$ & & & & $\mathrm{F}$ & & F & & R & $\mathrm{F}$ & $\mathrm{F}$ & \\
\hline & $366 \mathrm{~A}-20-2,85-87$ & C & G & - & & c & & & F F & $R$ & c & & & $\mathbf{R}$ & & & & $\mathrm{R}$ & $\mathbf{R}$ & $\mathbf{R}$ & & & C 1 & $\mathrm{~F}$ & \\
\hline & $366 \mathrm{~A}-20-3,65-67$ & C & G & & & C & & & R F & $\mathrm{R}$ & c & & & $\mathrm{R}$ & & & & - & $\mathrm{F}$ & $\mathrm{F}$ & & F & C 1 & $\mathrm{~F}$ & \\
\hline \multirow{20}{*}{$\begin{array}{l}\text { Stichocorys } \\
\text { delmontensis }\end{array}$} & $\begin{array}{l}366 \mathrm{~A}-20, \mathrm{CC} \\
366 \mathrm{~A}-21-1,95-97\end{array}$ & $\begin{array}{l}\mathrm{F} \\
\mathrm{C}\end{array}$ & $\begin{array}{l}M \\
G\end{array}$ & & & $\begin{array}{l}\mathrm{F} \\
\mathrm{C}\end{array}$ & & $\begin{array}{l}+\mathrm{F} \\
\mathrm{R}\end{array}$ & $\begin{array}{ll}F & F \\
R & -\end{array}$ & & $\begin{array}{l}\mathrm{F} \\
\mathrm{F}\end{array}$ & & & $\begin{array}{l}\mathrm{R} \\
\mathrm{R}\end{array}$ & & & & - & $\begin{array}{l}R \\
F\end{array}$ & $\begin{array}{l}\mathrm{R} \\
\mathrm{R}\end{array}$ & & & $\begin{array}{ll}\mathrm{F} & \mathrm{F} \\
\mathrm{C}\end{array}$ & $\begin{array}{l}\mathrm{F} \\
-\end{array}$ & \\
\hline & $366 \mathrm{~A}-21-2,62-64$ & $\mathrm{C}$ & G & & & C & & & $\mathrm{R}-$ & - $R$ & C & F & & $\mathrm{R}$ & R & & & - & c & F & & & c & - & \\
\hline & $366 \mathrm{~A}-21-3,65-67$ & c & G & & & c & & & $\mathrm{R}-$ & R & c & R & & $\mathrm{R}$ & & & & & c & $\mathrm{F}$ & & & c - & - & \\
\hline & $366 \mathrm{~A}-21-4,65-67$ & C & G & & & C & & & $\mathrm{F}-$ & & $R \quad R \quad R$ & $\mathrm{R}$ & & $\mathrm{F}$ & $\mathbf{R}$ & & & & $\mathrm{F}$ & $\mathrm{F}$ & - & & c - & - & \\
\hline & $366 \mathrm{~A}-21-5,65-67$ & c & G & & & C & & & R - & $\mathrm{R}$ & $\mathbf{R}$ & & $\mathrm{R}$ & c & & & & - & $\mathrm{R}$ & $\mathrm{F}$ & - & & $\mathrm{F}-\mathrm{C}$ & - & \\
\hline & $366 \mathrm{~A}-21-6,45-47$ & c & G & & & c & & R F & $F-$ & - $R$ & $\mathbf{R}$ & & $\mathbf{R}$ & $\mathbf{R}$ & & & & - & $\mathrm{F}$ & $\mathbf{R}$ & - & & $\mathrm{R}$ & - & \\
\hline & $366 \mathrm{~A}-21, \mathrm{CC}$ & c & M & & & c & & $R \mathrm{R}$ & $\mathbf{R}$ & & $\mathbf{R}$ & & & $\mathrm{F}$ & & & & - & $\mathrm{R}$ & $\mathbf{R}$ & - & & C & & \\
\hline & $366 \mathrm{~A}-22-1,85-87$ & C & G & & & c & & R F & $\mathrm{F}$ & F & $\mathrm{R} R$ & $\mathrm{R}$ & & $\mathbf{R}$ & & & & $\mathrm{R}$ & $\mathrm{F}$ & $\mathbf{R}$ & - & & $\mathrm{F}$ & & \\
\hline & $366 \mathrm{~A}-22-2,70-72$ & C & G & & & c & & R F & $\mathrm{F}$ & & R F & $\mathrm{F}$ & & $F$ & & $\mathrm{R}$ & $\mathrm{R}$ & $\mathrm{R}$ & $\mathrm{F}$ & $\mathrm{R} R$ & $\mathrm{R}$ & & $\mathrm{R}$ & & \\
\hline & $366 \mathrm{~A}-22, \mathrm{CC}$ & C & M & & & C $\mathrm{R}$ & & R F & F & & $F \quad R$ & $\mathbf{R}$ & & $\mathbf{R}$ & $\mathrm{R} R$ & $\mathbf{R}$ & & + & & $\mathrm{R}$ & $\mathrm{R}$ & $\mathrm{R}$ & c & & \\
\hline & $366 \mathrm{~A}-23-1,51-53$ & C & $\mathrm{M}$ & & & C & & R F & $\mathrm{F}$ & & & R & & $\mathrm{F}$ & & $\mathrm{R}$ & & $\mathrm{F}$ & $\mathrm{F}$ & $\mathrm{F}$ & $F$ & & $\mathrm{~F}$ & & \\
\hline & $366 \mathrm{~A}-23-2,70-72$ & c & M & & & c & & $\mathrm{R} R$ & $\mathrm{R}$ & & & $\mathbf{R}$ & $\mathrm{R}$ & $\mathrm{F}$ & & R & & $\mathrm{R}$ & & $\mathrm{F} R$ & $R$ & & $\mathrm{R}$ & & - \\
\hline & $366 \mathrm{~A}-23-3,65-67$ & c & $\mathrm{G}$ & & & C & & R F & $\mathrm{F}$ & & & $\mathrm{F}$ & $\mathrm{R}$ & $\mathrm{F}$ & & $R$ & & $\mathrm{R}$ & $\mathrm{F}$ & $\mathrm{R}$ & $\mathrm{C}$ & & $\mathrm{F}$ & & - \\
\hline & $366 \mathrm{~A}-23-4,65-67$ & C & M & & & C & & $\mathrm{RC}$ & C & & & & & $\mathrm{F}$ & & $\mathrm{R}$ & & F & F & R R & $\mathrm{C}$ & & $\mathbf{R}$ & & - \\
\hline & $366 \mathrm{~A}-23-5,65-67$ & $\mathrm{~F}$ & M & & & $\mathrm{F}$ & & $\mathrm{R} R$ & $\mathrm{R}$ & & $\mathbf{R}$ & & & $\mathbf{R}$ & & $\mathbf{R}$ & & $\mathbf{R}$ & & $\mathbf{R}$ & $\mathrm{F}$ & & $\mathrm{F}$ & & - \\
\hline & $366 \mathrm{~A}-23-6,45-47$ & C & M & & & C & & R - & - & & & & & $\mathrm{F}$ & & $\mathrm{F}$ & & $\mathbf{R}$ & & $\mathbf{R}$ & $\mathrm{F}$ & R & c & & - \\
\hline & $366 \mathrm{~A}-24-1,90-92$ & c & G & & -8 & $\mathrm{C}$ & & $\mathrm{F}-$ & - & $\mathrm{F}$ & & + & & $R$ & & C & & $\mathbf{R}$ & & $\begin{array}{ll}F & R \\
P & F\end{array}$ & $\mathrm{~F}$ & & C & & - \\
\hline & $\begin{array}{l}366 \mathrm{~A}-24-2,85-87 \\
366 \mathrm{~A}-24, \mathrm{CC}\end{array}$ & C & M & & -8 & C & & $\begin{array}{l}R- \\
F-\end{array}$ & - & & & $\begin{array}{lll}R & & \\
F & R\end{array}$ & & $\mathbf{R}$ & & $\mathbf{R}$ & & & $\mathrm{R}$ & $\begin{array}{ll}R & F \\
R & F\end{array}$ & $R$ & & C & & $\overline{-}$ \\
\hline & $\begin{array}{l}366 \mathrm{~A}-24, \mathrm{CC} \\
366 \mathrm{~A}-25-1,110-112\end{array}$ & $\begin{array}{l}\mathrm{C} \\
\mathrm{C}\end{array}$ & $\begin{array}{l}\text { G } \\
\text { G }\end{array}$ & & $\begin{array}{ll}-c \\
-c\end{array}$ & $\begin{array}{lll}\mathrm{C} & \\
\mathrm{C} & \mathrm{F}\end{array}$ & & & - & & & $\begin{array}{ll}F & R \\
R & R\end{array}$ & R R & $\begin{array}{l}\mathrm{F} \\
\mathrm{F}\end{array}$ & $\begin{array}{l}\mathrm{F} \\
\mathrm{R}\end{array}$ & 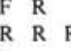 & $\mathrm{R}$ & $\begin{array}{l}R \\
F\end{array}$ & $\mathrm{~F}$ & $\begin{array}{ll}R & F \\
F & C\end{array}$ & $\mathrm{C}$ & $\begin{array}{l}R \\
R\end{array}$ & $\mathrm{~F}$ & & c - \\
\hline & $366 \mathrm{~A}-25, \mathrm{CC}$ & $\mathrm{F}$ & M & & $-F$ & $F \quad R$ & & R - & & & & & & $\mathrm{R}$ & & $\mathrm{R}$ & & & & F & $\mathrm{F}$ & & $\mathrm{F}$ & & - \\
\hline \multirow{8}{*}{$\begin{array}{c}\text { Cyrtocapsella } \\
\text { tetrapera }\end{array}$} & $366 \mathrm{~A}-26-1,66-68$ & C & M & & C : & $\mathrm{R} \quad \mathrm{R}$ & & $\mathrm{C}$ & & & & $\mathbf{R}$ & $\mathrm{F}$ & $\mathbf{R}$ & & $\mathrm{R} F \mathrm{~F}$ & $\mathrm{R}$ & & $\mathbf{R}$ & $\mathrm{F}$ & C & & - & & c \\
\hline & $366 \mathrm{~A}-26-2,57-59$ & C & & & C F & $\mathrm{F}$ & & $\mathrm{F}$ & & & & & R & $\mathrm{F}$ & & F & & & $\mathrm{F}$ & $\mathrm{F}$ & $C$ & & - & & C \\
\hline & $366 \mathrm{~A}-26-3,77-79$ & C & G & & $\mathrm{R}$ & C & & C & & & & & & C & $\mathrm{F}$ & $\mathrm{F}$ & & $\mathrm{R}$ & & $F \quad F$ & $c$ & & + & & $\mathrm{F}$ \\
\hline & $366 \mathrm{~A}-26-4,77-79$ & $\mathrm{~F}$ & M & & $\mathrm{F}$ & - & & $\mathrm{F}$ & & & & & $\mathbf{R}$ & $\mathrm{F}$ & & R & & & & R F & $\mathrm{F}$ & & - & & $\mathbf{R}$ \\
\hline & $366 \mathrm{~A}-26-5,55-57$ & C & G & & R - & - & & $\mathrm{F}$ & & & & & & $\mathrm{C}$ & F & $F R$ & & $\mathrm{R}$ & & C & $c$ & & - & & C \\
\hline & $366 \mathrm{~A}-26, \mathrm{CC}$ & $\mathrm{R}$ & M & & & - & & $\mathrm{R}$ & & & & & $\mathrm{R}$ & $\mathrm{R}$ & & $+R$ & & & & $\mathrm{R}$ & $\mathrm{R}$ & & - & & $\mathbf{R}$ \\
\hline & 366A-27-1,113-115 & c & & & $\mathrm{R}$ - & - & & C & & & & & $\mathrm{R}$ & $\mathrm{F}$ & & $+\mathrm{R}$ & & & & $\mathrm{R} R$ & $\mathrm{C}$ & & - & $\mathbf{R}$ & $\mathrm{R} \mathrm{C}$ \\
\hline & $366 \mathrm{~A}-27-2,35-37$ & c & M & & c. & - & & $\mathrm{F}$ & & & & & & $\mathrm{F}$ & & $\mathbf{R}$ & & $\mathrm{F}$ & & $\mathrm{F}$ & $\mathrm{C}$ & & & & C \\
\hline & $366 \mathrm{~A}-27-3,95-97$ & $\mathrm{~F}$ & $\mathrm{M}$ & & $\mathrm{F}-\mathrm{r}$ & - & & $\mathrm{R}$ & & & & & & - & - & - & & F & & $\mathrm{R}$ & $\mathrm{R}$ & & & & F \\
\hline & $366 \mathrm{~A}-27-4,100-102$ & c & G & & c - & - & & $\mathrm{R}$ & & & & & & - & - & - & & $\mathrm{F}$ & & R & $\mathrm{C}$ & & & & R \\
\hline & $366 \mathrm{~A}-27-5,65-67$ & c & $\mathrm{M}$ & & C & & & $\mathrm{F}$ & & & & & R & - & - & - & & $\mathrm{R}$ & - $R$ & R F & $\mathbf{R}$ & & & & \\
\hline & $366 \mathrm{~A}-27-6,55-57$ & c & $\mathrm{G}$ & & C & & & $\mathrm{R}$ & & & & & & - & - & - & & $\mathrm{F}$ & - & $\mathbf{R}$ & $\mathrm{C}$ & & & & $\mathrm{R}$ \\
\hline & $366 \mathrm{~A}-27, \mathrm{CC}$ & c & $\mathrm{M}$ & & c & & & & & & & & & - & & - & & & - & $\mathrm{R}$ & $\mathrm{C}$ & & & & $\mathbf{R}$ \\
\hline & 366A-28-1, 95-97 & $\mathrm{F}$ & $P$ & & F & & & & & & & & & & & & & & $-R$ & $\mathrm{R} R$ & $\mathrm{~F}$ & & & & \\
\hline & $366 \mathrm{~A}-28-2,67-69$ & $\mathrm{~F}$ & $\mathrm{M}$ & & $\mathrm{F}$ & & & & & & & & & & & & & R & - & $\mathrm{R}$ & $\mathrm{F}$ & & & & \\
\hline Lychnocanoma & $366 \mathrm{~A}-28-3,55-57$ & c & $\mathrm{M}$ & & c & & & $\mathrm{R}$ & & & & & & & & & & & c & - & c & & & $\mathrm{R}$ & R \\
\hline elongata & $366 \mathrm{~A}-28-4,47-49$ & C & M & & c & & & $\mathrm{F}$ & & & & & $\mathrm{R}$ & & & & & & $\mathrm{R}$ & - & C & & & & \\
\hline & $366 \mathrm{~A}-28-5,55-57$ & C & M & & C & & & & & & & & $\mathrm{R}$ & & & & & $\mathrm{F}$ & F & - & c & & & & \\
\hline & $366 \mathrm{~A}-28-6,51-53$ & c & $\mathrm{G}$ & & c & & & $\mathrm{R}$ & & & & & R & & & & & $\mathrm{F}$ & $\mathrm{R}$ & & c & & & & C \\
\hline & $366 \mathrm{~A}-28, \mathrm{CC}$ & $\mathbf{R}$ & $P$ & & $\mathbf{R}$ & & & & & & & & & & & & & R & R & & $\mathrm{R}$ & & & & \\
\hline & 366A-29-1, 85-87 & c & $\mathrm{M}$ & & C & & & & & & & & & & & & & F & F & & c & & & & \\
\hline & $366 \mathrm{~A}-29-2,71-73$ & c & $\mathrm{G}$ & & $\mathrm{F}$ & & & $\mathbf{R}$ & & & & & $\mathrm{R}$ & & & & + & F & $\mathrm{R}$ & & F & & & & $\mathbf{R}$ \\
\hline & $366 \mathrm{~A}-29-3,50-52$ & c & G & & c & & & & & & & & $\mathrm{R}$ & & & & & R & $\mathrm{F}$ & & c & & & & $\mathrm{F}$ \\
\hline & $366 \mathrm{~A}-29-4,51-53$ & C & $\mathbf{P}$ & & $\mathrm{R}$ & & & & & & & & & & & & & 1: & c & & C & & & . & \\
\hline & $366 \mathrm{~A}-29-5,56-58$ & $\mathbf{R}$ & $\mathbf{P}$ & & $\mathrm{R}$ & & & & & & & & & & & & & $\mathbf{R}$ & $\mathbf{R}$ & & $\mathbf{R}$ & & & & \\
\hline
\end{tabular}


TABLE 1B

Oligocene Radiolarians at Site 366 (Holes 366 and 366A)

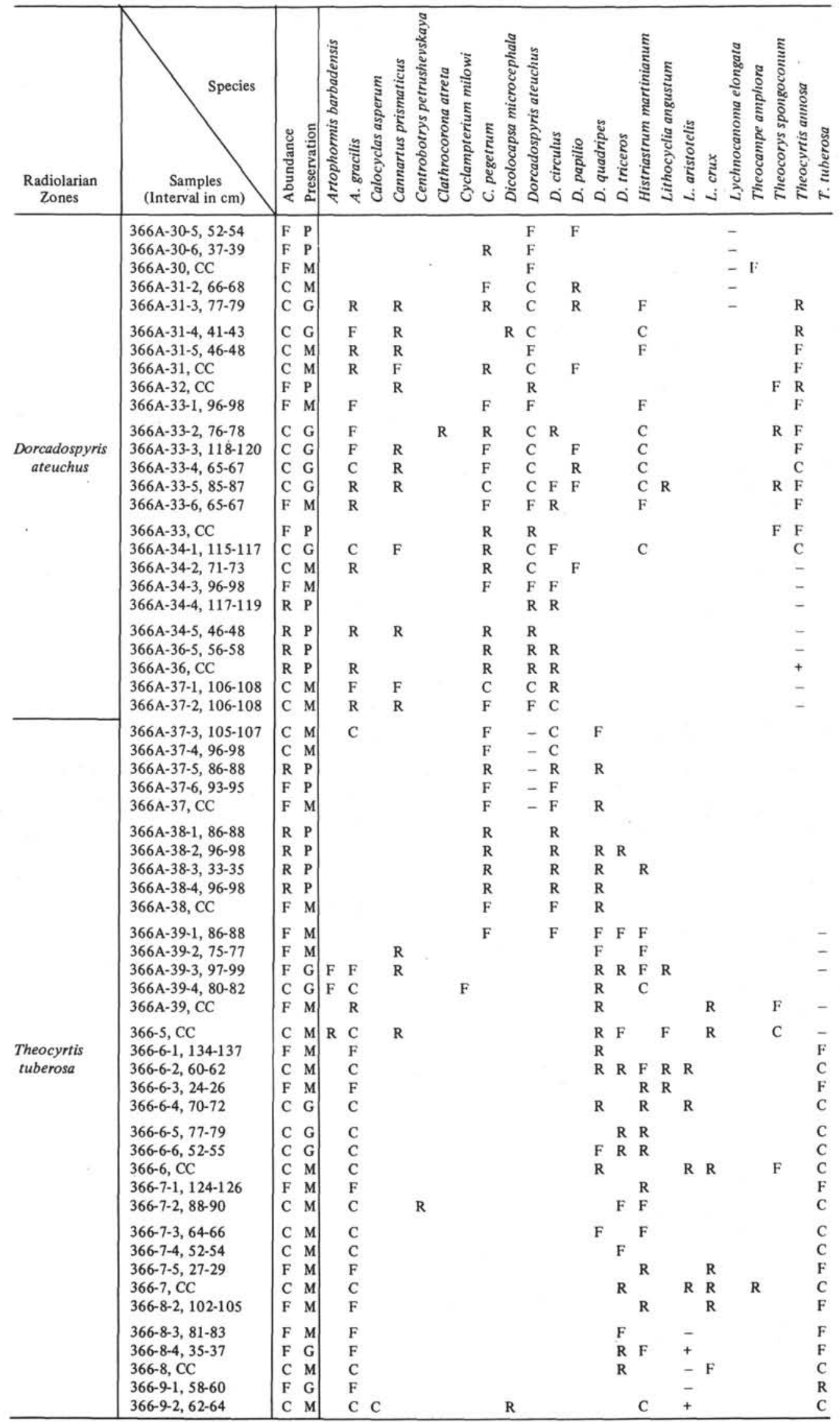


TABLE 1C

Eocene Radiolarians at Site 366.

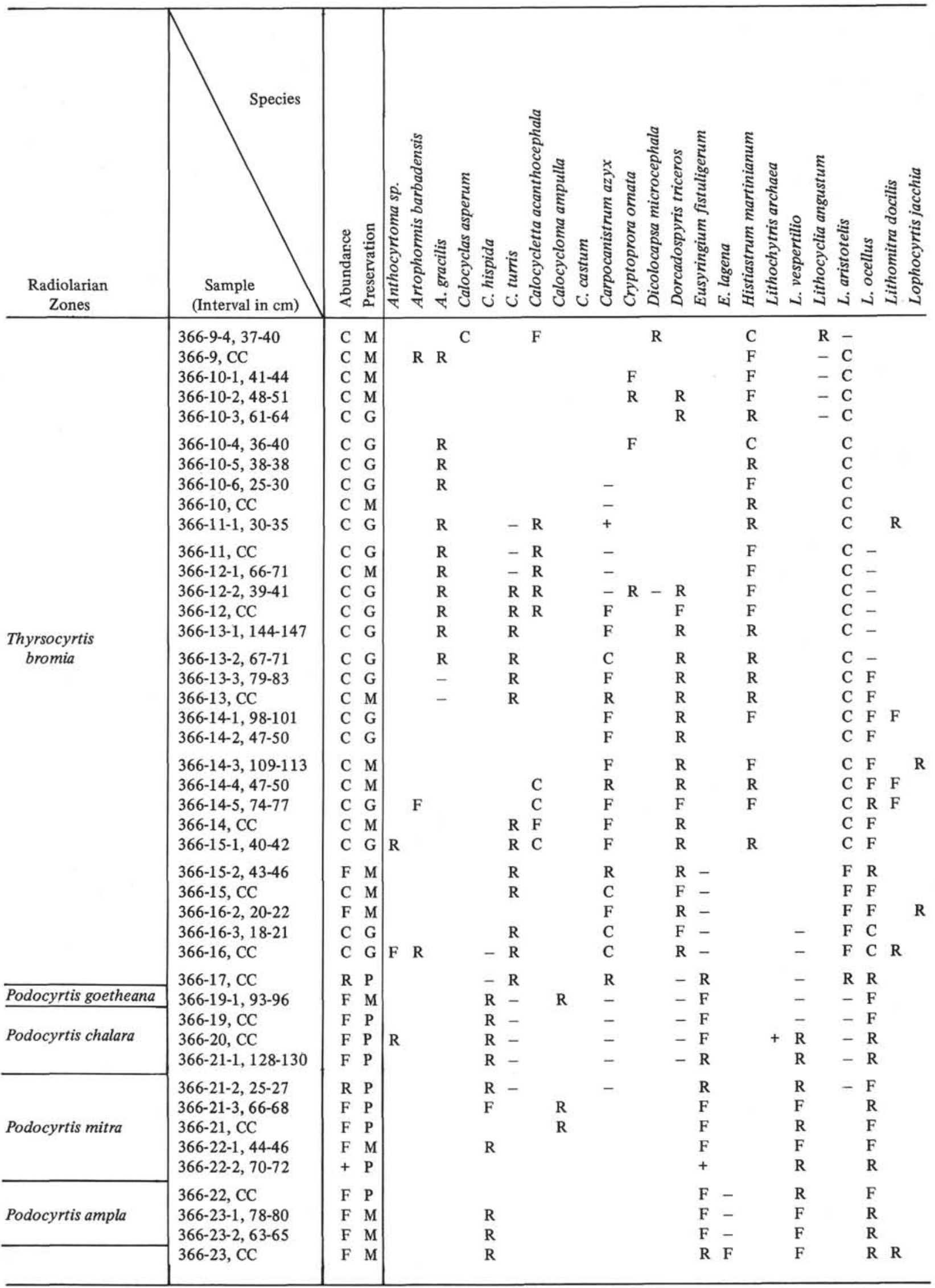




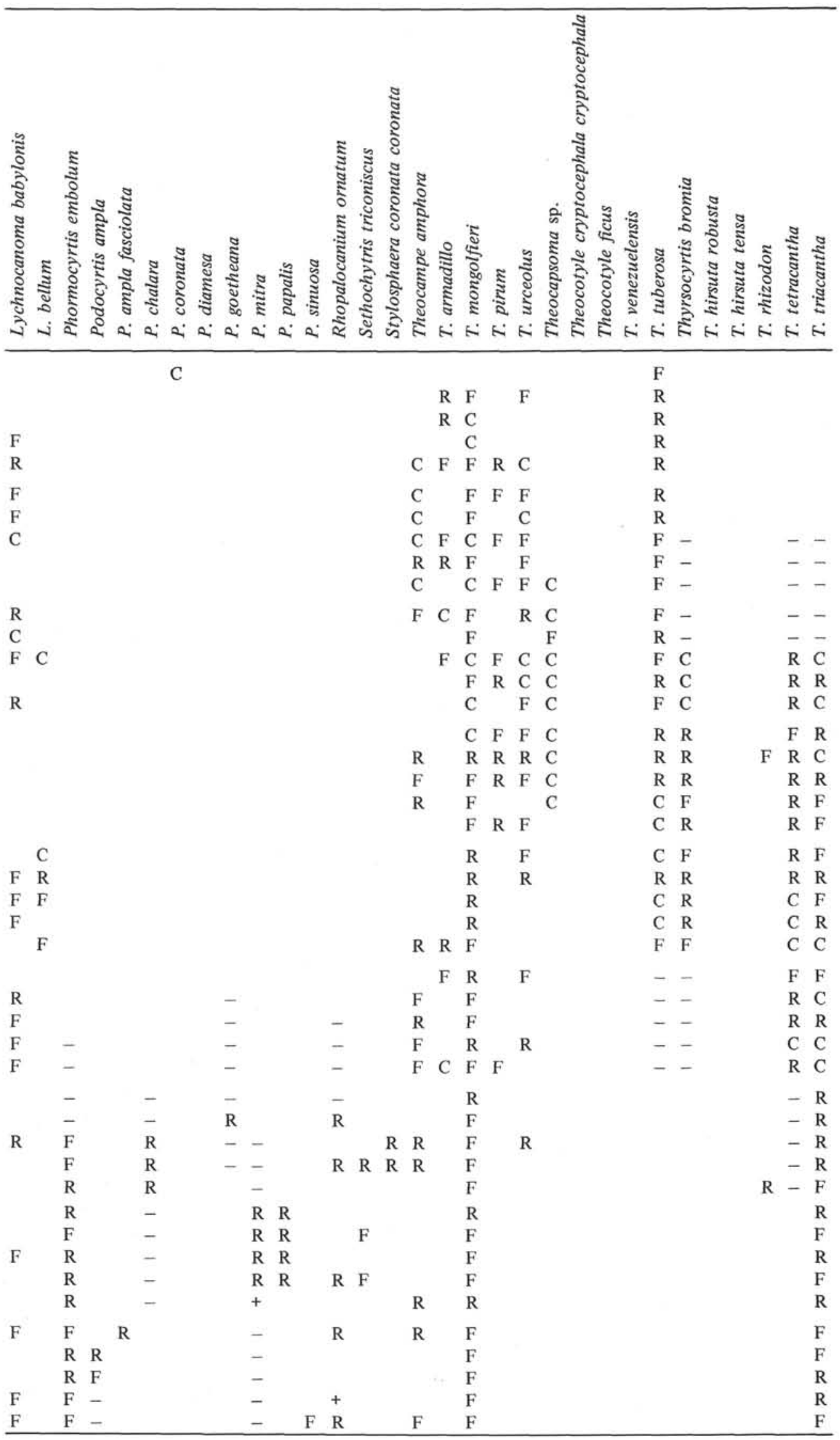




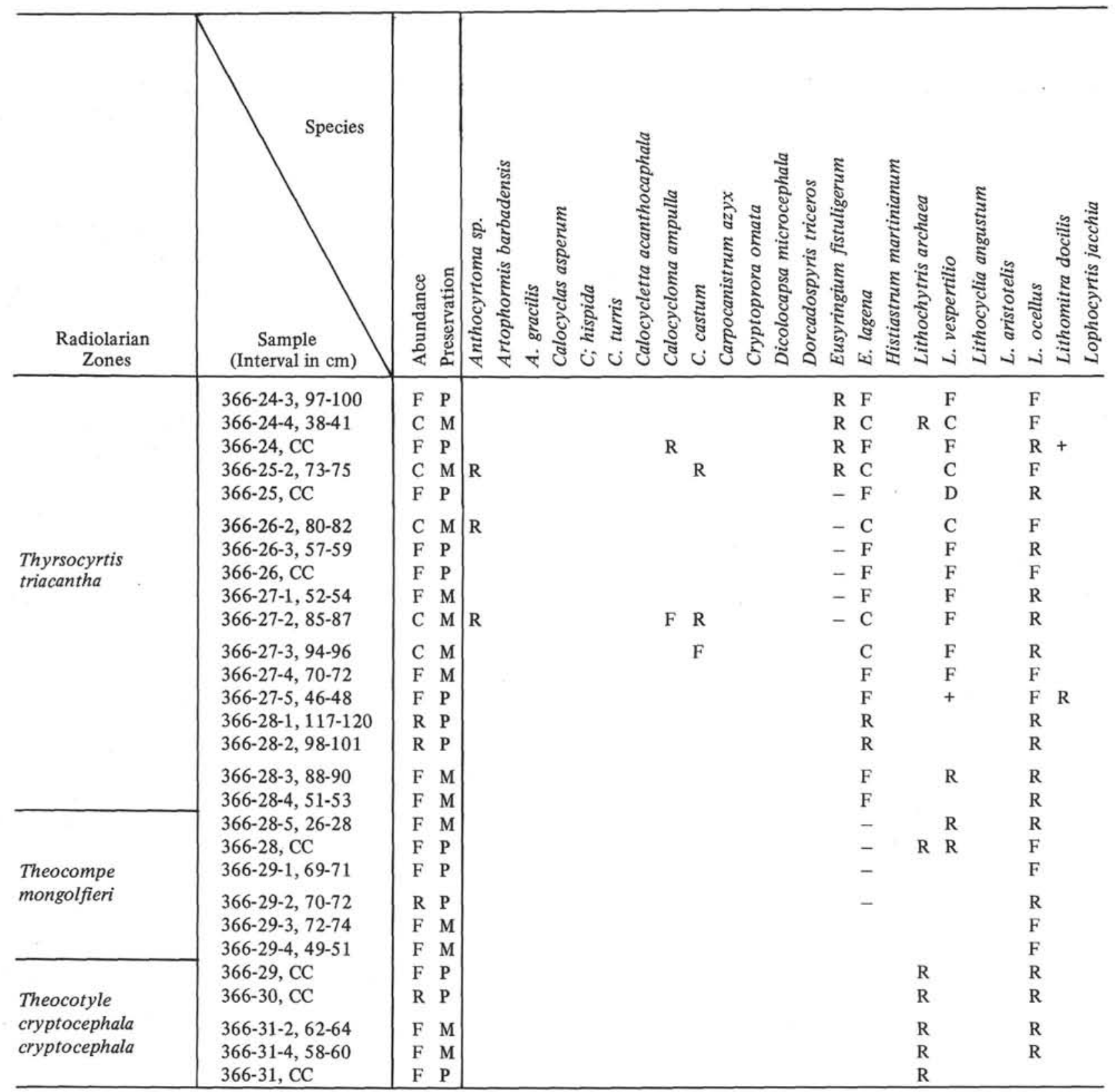

samples to allow the determination of zonal boundaries with a fair degree of confidence.

No identifiable radiolaria were seen in samples from the lower Eocene and Paleocene interval below Core $366-31$ (depth $=622$ meters).

\section{Site 367}

Radiolarians are present within only a small fraction of the section cored at Site 367. The assemblages are sufficiently well preserved to allow age determination in a few cores of upper Pleistocene and Eocene age. Radiolarian fragments were observed in several of the Mesozoic cores, but in all cases the original skeletal material had been replaced by pyrite or calcite, and identification of the fragments was not possible.

\section{Pleistocene}

Core 1 contains rare specimens of moderately well preserved radiolarian species indicative of a Pleistocene age; these taxa include Ommatartus tetrathalamus, Lamprocyclas maritalis polypora, Siphocampe corbula, Axoprunum angelinum, and Pterocanium trilobum. The presence of $A$. angelinum in Sample 367-1, CC, suggests an age greater than 0.4 m.y. Included with the Pleistocene species are scattered middle and early Tertiary forms, including Calocycletta virginis, Cannartus laticonus, Stichocorys delmontensis, and Rhopalocanium sp. The presence of reworked contaminants is not surprising in view of the probable outcrops of Tertiary strata along the adjacent continental margin. The base of the Pleistocene was not 


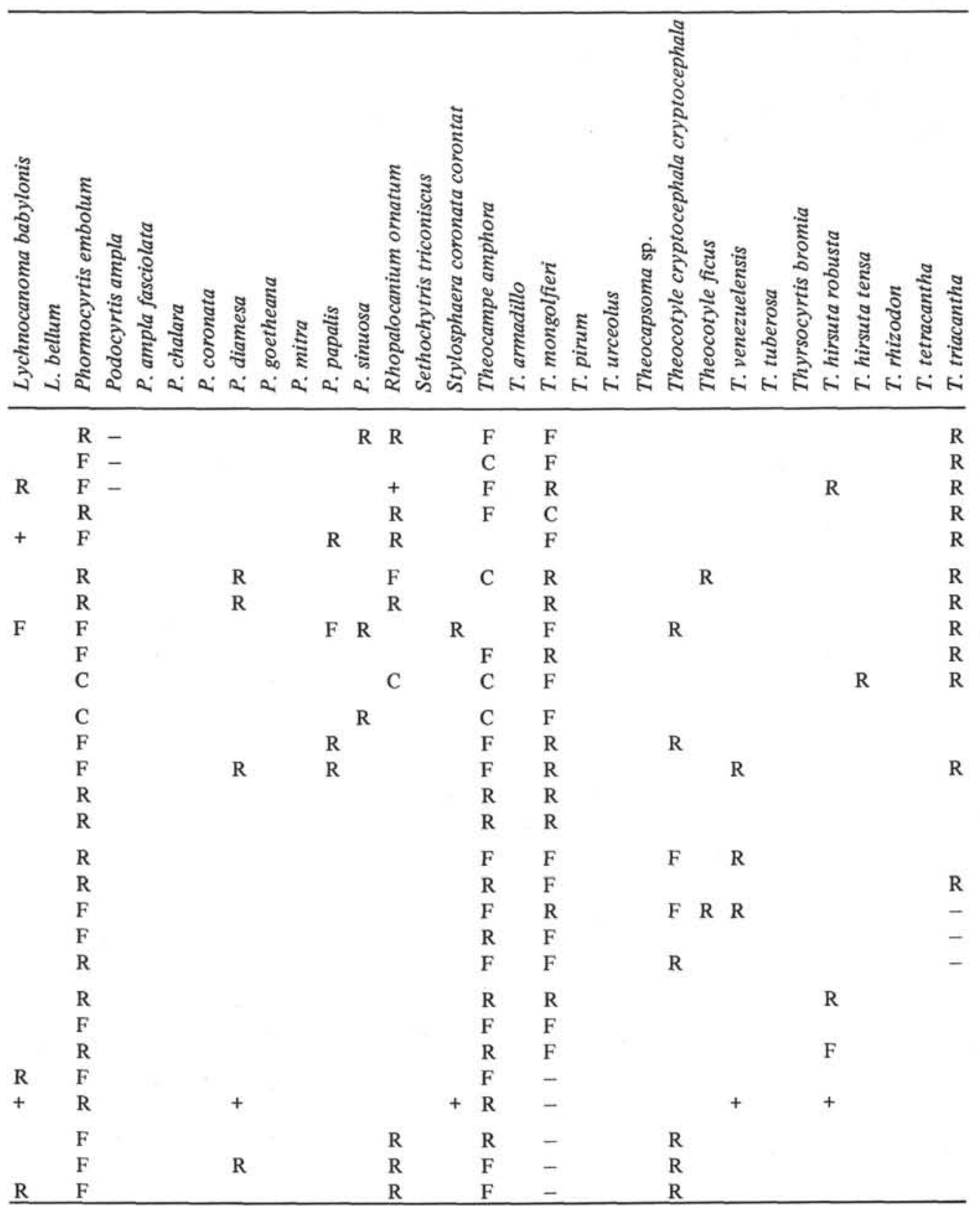

identified, since Cores 2 through 7 were devoid of radiolarians.

\section{Eocene}

Core 8 contains common specimens of moderately preserved radiolarians diagnostic of the upper Eocene Thyrsocyrtis bromia Zone. The following list includes most of the stratigraphically useful taxa, and indicates the relative abundance of each form:

\begin{tabular}{lc}
\hline \multicolumn{1}{c}{ Species } & Abundance \\
\hline Thyrsocyrtis bromia & $\mathrm{C}$ \\
Lithocyclia aristotelis & $\mathrm{C}$ \\
Thyrsocyrtis triacantha & $\mathrm{C}$ \\
Dorcadospyris triceros & $\mathrm{C}$
\end{tabular}

Theocampe mongolfieri

Theocampe urceolus

Histiastrum martinianum

Calocyclas turris

Thyrsocyrtis tetracantha

Carpocanistrum azyx

Lychnocanoma babylonis

Clathrocycloma parcum

Cryptoprora ornata

Theocampe amphora

Theocampe armadillo

Anthocyrtoma sp.

Lychnocanoma bellum

Artophormis gracilis

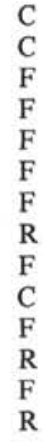

Core 10 contains rare and very poorly preserved fragments of lower and middle Eocene species, 
TABLE 3

Early Miocene Radiolarians at Site 368

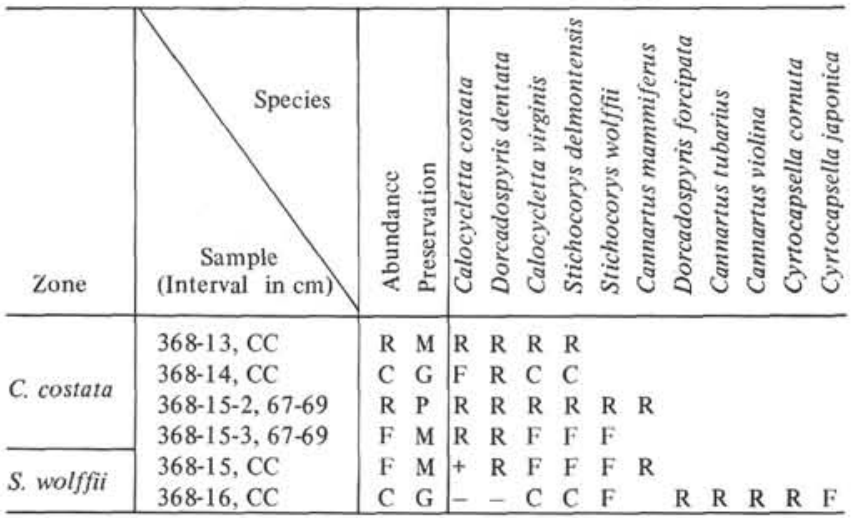

including Stylosphaera coronata coronata, $S$. coronata sabaca, S. coronata laevis, Lithochytris archaea, Podocyrtis sinuosa, Amphicraspedum prolixum, and Theocampe amphora. The presence of these taxa, together with the absence of Theocampe mongolfieri s.s., is consistent with an age corresponding to the Theocotyle cryptocephala cyrptocephala Zone.

Core 12 contains rare, poorly preserved specimens of Buryella clinata, $S$. coronata coronata, $T$. amphora, $T$. urceolus, Phormocyrtis embolum, and $S$. coronata sabaca; this assemblage corresponds to the lower Eocene $P$. striata striata Zone or $B$. clinata Zone.

Core 14 can be assigned to the Bekoma bidartensis Zone of lowermost Eocene or uppermost Paleocene age, based on common and poorly preserved specimens of Buryella tetradica, Lophocyrtis biaurita, Phormocyrtis turgida, $P$. striata exquisita, Thecosphaerella rotunda, $L$. archaea, and $S$. coronata sabaca. Radiolarians are absent in the Paleogene sediments below Core 14.

There is no evidence of reworking or redeposition in any of the Eocene radiolarian assemblages, although the abundance of diagnostic forms is not sufficient to rule out the possibility of reworking.

\section{Cretaceous and Upper Jurassic}

Within the stratigraphic interval including Cores 24 through 34 , poorly preserved radiolarian fragments were identified in several core catcher samples. Virtually all recognizable radiolarian fragments had experienced diagenesis, with the silica replaced by either pyrite or calcite. Radiolarian fragments from the vari-colored siltstones and mudstones were almost exclusively replaced by pyrite. Scattered radiolarian fragments were also present in washed samples and in thin sections prepared from the lithified white limestone units. Most of these forms were totally replaced by calcite, with many details of the original test morphology no longer visible; a few pyritized fragments co-occur with the calcified tests in some of these samples. In general the abundance of the fragments appeared greatest in the thinly laminated, gray to brown siltstone units, with lesser amounts in the green and red mudstones, and only trace amounts in the black shaly units and the more massive white limestones.
Identification of radiolarian species within the Mesozoic sediments was not possible with ordinary transmitted light techniques because of the poor preservation of most fragments. Several specimens representing the genera Dictyomitra, Holocryptocapsa, and Staurosphaera were identified, but most specimens were too poorly preserved to allow even a generic name to be assigned.

\section{Site 368}

Significant quantities of radiolarians were identified within three stratigraphic intervals of the Cenozoic at Site 368: the late Pleistocene, the early Miocene, and the late Paleocene to middle Eocene (see Tables 2 and 4). Scattered fragments of radiolarians, many of which had been replaced by pyrite, were observed within the sparsely fossiliferous clays, shales, and porcellanites below Core 44 which are of Paleogene and Cretaceous age. These fragments were generally not sufficiently abundant nor sufficiently well preserved to be of stratigraphic value (see discussion in chapter on Mesozoic radiolaria by Helen P. Foreman).

\section{Pleistocene}

Cores 1 and 2 contain radiolarians diagnostic of the Pleistocene, together with rare reworked taxa of middle Tertiary age. The base of the Pleistocene was not identified, since the underlying cores (3 through 12) were barren of radiolarians. Cores 1 and 2 may therefore be restricted to the upper Pleistocene. Diagnostic taxa in these two cores included Axoprunum angelinum, Eucyrtidium calvertense, Lamprocyrtis hannai, Lamprocyclas maritalis martalis, L. maritalis polypora, L. haysi, Pterocanium trilobum, and Ommatartus tetrathalamus. Reworked Tertiary species included Calocycletta virginis, Stichocorys peregrina, and Calocycletta costata. The low abundance of radiolaria in these two cores is partly due to dilution by a significant quantity of detrital mineral grains which occur within the coarse fraction $(>62 \mu \mathrm{m})$.

\section{Miocene}

Radiolarians of early Miocene age were identified within Samples 13, CC, through 16, CC (see Table 2). Abundance of radiolarians in these cores ranges from rare to common, and preservation ranges from moderate to good. The base of the Calocycletta costata Zone was identified within Core 15. Radiolarians disappear abruptly below Core 16 . No indications of reworking were seen in any of the middle Miocene radiolarian assemblages in these four cores.

\section{Late Paleocene-Middle Eocene}

Samples from Cores 27 through 30 contain rare and moderately to poorly preserved radiolarians which may be assigned to the middle Eocene Phormocyrtis striata striata Zone. This age designation is based on the cooccurrence of Buryella clinata and Stylosphaera coronata sabaca in all samples, and the absence of Theocampe mongolfieri sensu strictu.

Samples from Cores 32 through 44 have been examined by Helen P. Foreman; results of these 
TABLE 3A

Miocene Radiolarians at Hole 369A

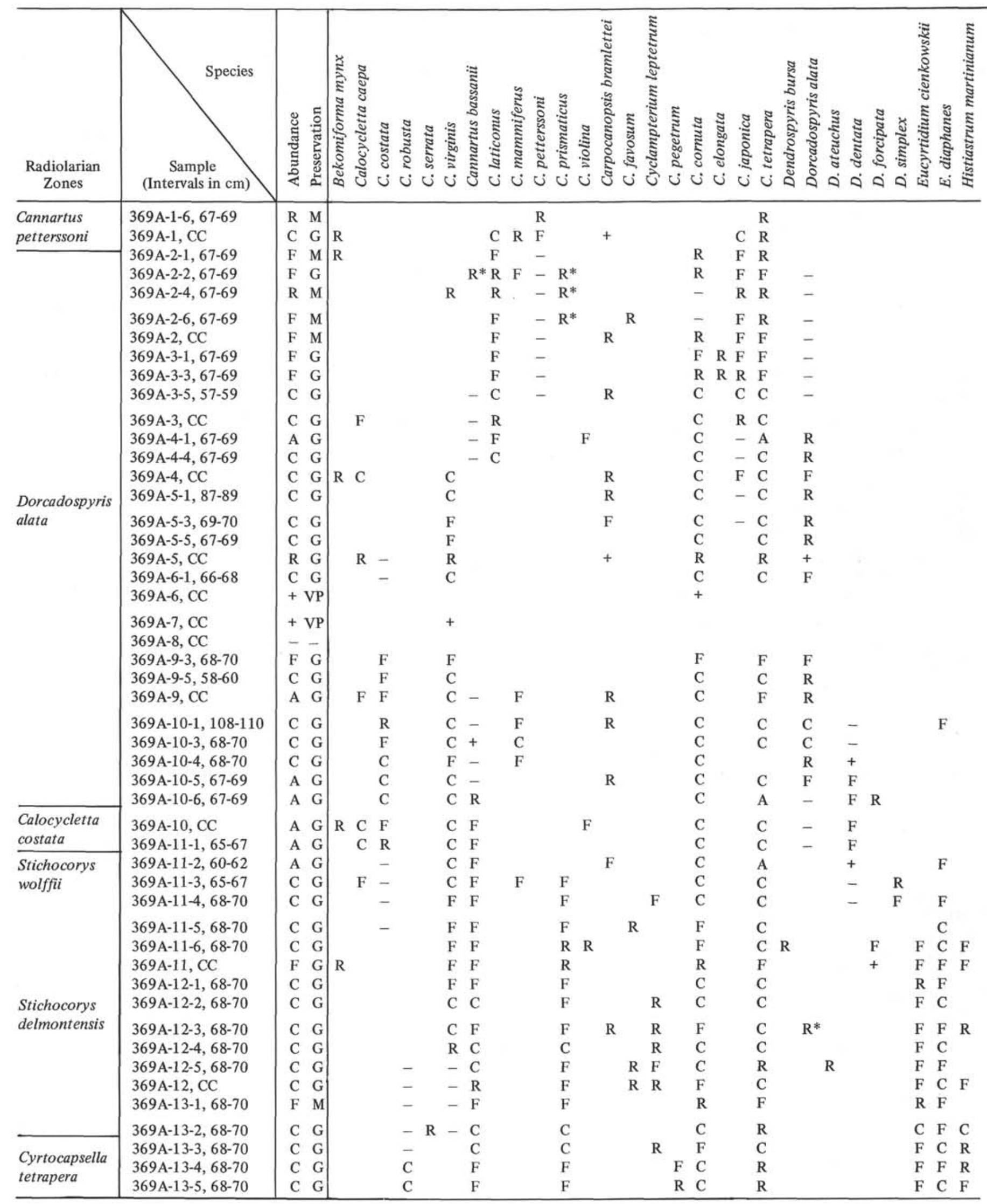

*Possible reworking or down-hole contamination. 
TABLE 3A - Continued

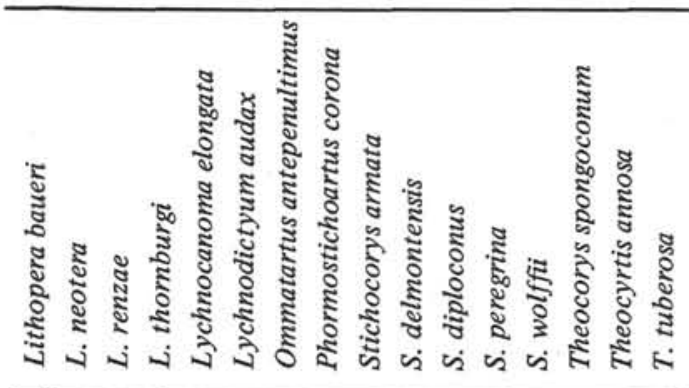

\begin{tabular}{|c|c|c|c|c|c|c|c|c|}
\hline & - & & & & & $\mathrm{R}$ & & \\
\hline $\mathrm{R}$ & - & & $\mathrm{R}$ & + & & $\mathrm{C}$ & R & \\
\hline R & - & & & & & $\mathrm{F}$ & & \\
\hline-1 & $\mathbf{R}$ & $\mathrm{R}$ & & & $\mathrm{R}$ & $\mathrm{R}$ & & \\
\hline- & + & $\mathrm{R}$ & & & & $\mathrm{R}$ & & \\
\hline & $\mathbf{R}$ & $\mathrm{R}$ & & & & $\mathrm{R}$ & & $\mathrm{R}^{*}$ \\
\hline & $\mathrm{R}$ & & & & & $\mathrm{R}$ & & \\
\hline & $\mathbf{R}$ & & & - & & $\mathrm{R}$ & & \\
\hline & $\mathrm{R}$ & & & - & & $\mathrm{R}$ & & \\
\hline & $\mathrm{R}$ & & & & F & $\mathrm{F}$ & & \\
\hline & C & F & & $\mathrm{F}$ & F & $\mathrm{F}$ & & \\
\hline & $\mathrm{R} \quad \mathrm{R}$ & R & & $\mathrm{F}$ & $\mathrm{C}$ & F & C & \\
\hline & $F$ & & & $\mathrm{~F}$ & C & C & C & $\mathrm{R}^{*}$ \\
\hline & $\mathrm{R}$ & & & $\mathrm{F}$ & F & $F$ & & \\
\hline & $\mathrm{R}$ & & & $\mathrm{R}$ & $\mathrm{R}$ & C & $\mathrm{F}$ & $\mathrm{R}^{*}$ \\
\hline & $\mathrm{R}$ & $\mathrm{F}$ & & $\mathrm{R}$ & $\mathbf{R}$ & $\mathrm{C}$ & & $\mathrm{R}^{*}$ \\
\hline & $\mathrm{R}$ & C & & F & F & $\mathrm{C}$ & & \\
\hline & $\mathrm{R}$ & & & + & $\mathrm{R}$ & $\mathrm{R}$ & & \\
\hline & $\mathrm{F}$ & F & & $\mathrm{R}$ & $\mathrm{R}$ & C & & \\
\hline
\end{tabular}

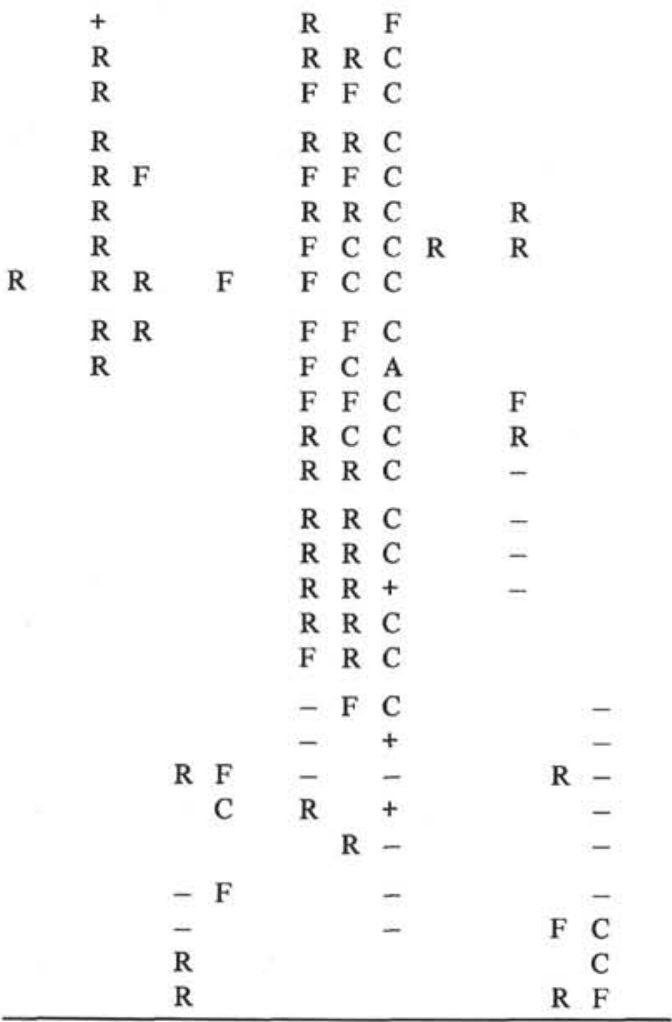

biostratigraphic and taxonomic studies are discussed separately in the appendix of this report.

All assemblages examined from Cores 27 through 44 consist of taxa with overlapping stratigraphic ranges; consequently there is no indication of reworking of older components.

\section{Site 369/369A}

The two holes drilled at Site 369 continuously cored the upper 488 meters of sediment, which ranges in age from Quaternary to upper Aptian. Radiolarians are sufficiently abundant and well preserved for reliable paleontological age control within five stratigraphic intervals:

\begin{tabular}{lcl}
\hline \multicolumn{1}{c}{ Core } & Depth Interval $(\mathrm{m})$ & \multicolumn{1}{c}{ Age } \\
\hline 1 & $0.0-1.0$ & Pleistocene \\
1A to 13A & $50.0-164.0$ & Middle to lower Miocene \\
13A to 32A & $164.0-346.0$ & Oligocene \\
33A to 35A & $355.5-374.0$ & Middle Eocene \\
35A to 39A & $374.5-412.5$ & Maestrichtian to Campanian \\
\hline
\end{tabular}

Elsewhere within the section, radiolarians are absent or are present only as poorly preserved and unidentifiable fragments.

It was generally possible to identify radiolarian zones within the biostratigraphic framework which is applicable in low latitude regions (Riedel and Sanfilippo, 1974). However, even the samples showing very good preservation commonly lacked several of the diagnostic taxa which are key stratigraphic indicators in tropical assemblages. For example, some species belonging to the genus Dorcadospyris are notably rare, Cyrtocapsella tetrapera appears to extend well down into the Oligocene in scattered samples, and the critical zonal indicator species for the upper Oligocene-lower Miocene (Lychnocanoma elongata) is virtually absent, though this absence may be indicative of an unconformity. Some of the uncertainty in zonal age determination may perhaps be attributed to erosional hiatuses or to reworking of the assemblages, factors which may well be of importance in view of the physiographic setting of this site. An additional factor may be the higher latitude biogeographic province of Site 369 in comparison with those in tropical regions (e.g., Site 366). The radiolarians at Site 369 bear a very close resemblance to the Mediterranean assemblages described by Sanfilippo et al. (1973). Additional work on the samples may lead to a revised and more refined zonation for the Oligocene through middle Miocene. Precise correlations can then be established with the standard calcareous microfossil zonations.

\section{Pleistocene (Core 1)}

The top of Core 1 (Sample 369-1-1, 144-145 cm) contains rare, moderately preserved radiolarians (including L. maritalis maritalis, L. maritalis polypora, and $A$. angelinum) which are consistent with a Pleistocene age. Scattered reworked Tertiary specimens are also present. Radiolaria were totally absent in the upper five cores except for this one sample. 
TABLE 3B

Oligocene Radiolarians at Hole 369A

Dorcadospyris ateuchus

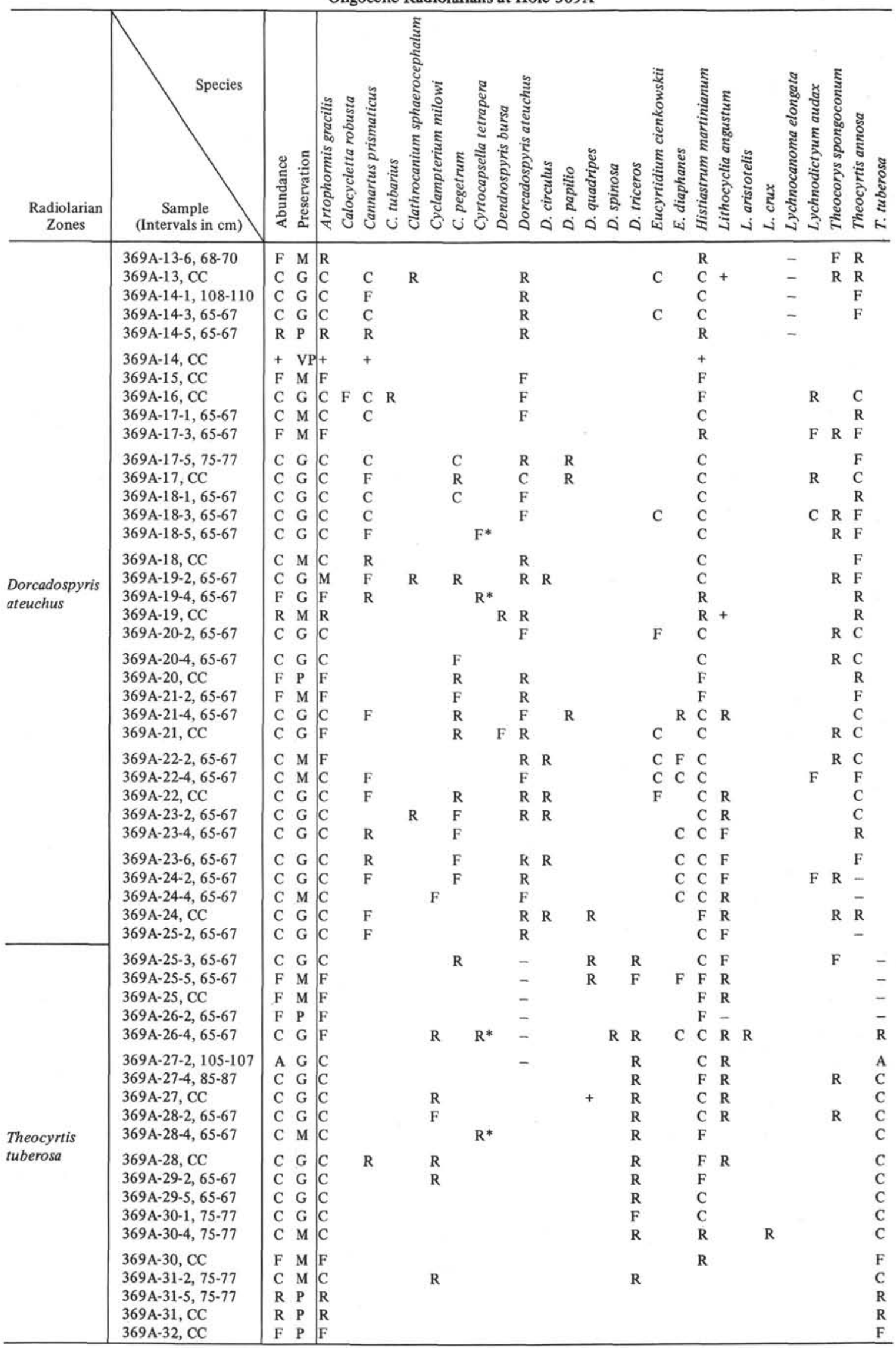


TABLE 4

Radiolarians at Site 368

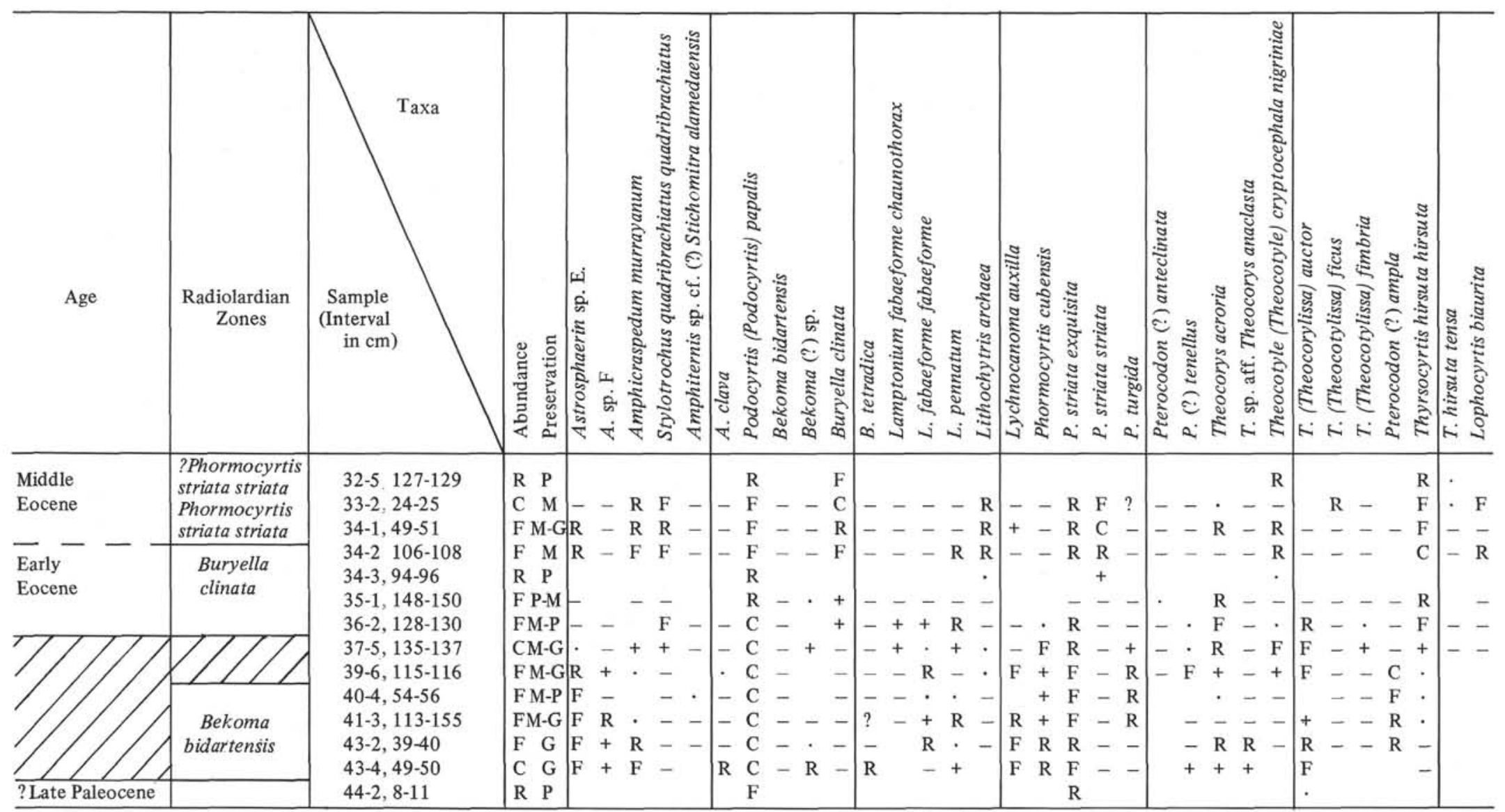


Middle to Lower Miocene

(Cores 1A to 13A; see Table $3 \mathrm{~A}$ )

These cores contain diverse and generally wellpreserved radiolarian assemblages of tropical to subtropical affinities which span six radiolarian zones of middle and lower Miocene age. All zonal boundaries can be identified with good reliability; however, there is some uncertainty concerning the base of the $S$. wolffii Zone because of the relatively rare occurrence of this species. There is no direct evidence of unconformities within this section, but the highly variable thicknesses of the radiolarian zones may reflect considerable variation in net accumulation rates.

There is evidently an unconformity present near the base of Core 366A-13. The Lychnocanoma elongata Zone is evidently missing, since two of the species which are characteristically present in this zone $(C$. robusta, $L$. elongata) are present only in conjunction with $C$. tetrapera (Table $3 \mathrm{~A})$.

\section{Oligocene (Cores 13A through 32A; see Table 3B)}

Cores $13 \mathrm{~A}$ through $32 \mathrm{~A}$ represent a relatively complete Oligocene section in which radiolarians are generally common and well preserved. There is some uncertainty in identifying some zonal boundaries, however, because two of the definitive species ( $L$. elongata, $L$. angustum) are relatively rare. The presence of $L$. elongata within only three samples (Core 369A-13; see Table 3A) may perhaps indicate an unconformity near the Miocene/Oligocene boundary. L. angustum is virtually absent from Cores $28 \mathrm{~A}$ through $32 \mathrm{~A}$ (see Table 3B), even through these cores are apparently of lower Oligocene age, based on the absence of diagnostic Eocene genera. Consequently the base of the $T$. tuberosa Zone is poorly defined.

An unconformity near the base of Core $32 \mathrm{~A}$ separates lower Oligocene from middle Eocene material.

\section{Middle Eocene (Cores 33A to 35A)}

Cores $33 \mathrm{~A}$ to $35 \mathrm{~A}$ contain poorly preserved but identifiable fragments of radiolarians which indicate a middle Eocene age. Core 33A and Section 1 of Core $34 \mathrm{~A}$ are in the $P$. chalara Zone, based on the presence of $P$. chalara, T. mongolfieri, $E$. fistuligerum, $P$. embolum, $L$. vespertilio, $C$. hispida, $P$. papalis, and $T$. triacantha. Samples 369A-34, CC, through 369A-35-5, 65-67 cm, are in the P. mitra Zone, based on the presence of $P$. trachodes, $T$. triacantha, E. fistuligerum, $P$. mitra, $L$. vespertilio, and $T$. mongolfieri. An unconformity is present between Samples 369A-35-5, $65-67 \mathrm{~cm}$, and 369A-35, CC, below which is Upper Cretaceous material.

\section{Maestrichtian to Campanian (Cores 35A through 39A)}

Cores $35 \mathrm{~A}$ through $39 \mathrm{~A}$ contain white chalks of Upper Cretaceous age, within which radiolarians are rare to common and of moderate to good preservation. These assemblages are discussed in a separate chapter of this volume (by Helen P. Foreman).

\section{Site 370}

Site 370 contains radiolarians sufficiently well preserved to allow age estimation only within select intervals of middle Eocene through early Miocene age (Cores 3 through 12). Early Cenozoic sediments (Paleocene and lower Eocene) contain poorly preserved radiolarian tests; most of the silica has been remobilized into chert, with only rare fragments remaining which resemble the original morphologies of the radiolarian skeletal material. Mesozoic sediments at Site 370 appear totally devoid of biogenic silica.

Radiolarians are absent in Cores 1 and 2. Core 3 contains a diverse and well-preserved radiolarian assemblage of probable early or middle Miocene age; assignment of a precise zonal age is difficult because of extensive mixing of taxa whose stratigraphic ranges do not overlap. This apparent mixing may be either a result of processes of erosion and redeposition, or may be an artifact produced if sediment were allowed to enter the empty core barrel inadvertently within a "washed" interval. In either case the faunal assemblages in the Miocene cores at this site have uncertain biostratigraphic significance, and the age assignments are only approximate. Core 3 is tentatively assigned to the Stichocorys wolffii Zone, based on the following taxa:

\begin{tabular}{lc}
\hline \multicolumn{1}{c}{ Species } & Abundance \\
\hline Cyrtocapsella tetrapera & $\mathrm{C}$ \\
Cyrtocapsella cornuta & $\mathrm{C}$ \\
Stichocorys delmontensis & $\mathrm{C}$ \\
Calocycletta virginis & $\mathrm{C}$ \\
Cyrtocapsella japonica & $\mathrm{F}$ \\
Cannartus violina & $\mathrm{F}$ \\
Cannartus tubarius & $\mathrm{R}$ \\
Lychnocanoma elongata & $\mathrm{R}$ \\
Cannartus bassanii & $\mathrm{F}$ \\
Stichocorys armata & $\mathrm{R}$ \\
Dorcadospyris dentata & $\mathrm{R}$ \\
Cyclampterium leptetrum & $\mathrm{R}$ \\
Dorcadospyris simplex & + \\
Stichocorys wolffii & $\mathrm{F}$ \\
Cannartus prismaticus & $\mathrm{R}$ \\
Carpocanopsis favosum & $\mathrm{R}$ \\
Eucyrtidium cienkowskii & $\mathrm{F}$ \\
Carpocanopsis bramlettei & $\mathrm{R}$ \\
Calocycletta serrata (Reworked ?) & $\mathrm{R}$ \\
Calocycletta costata (Down-hole contamination ?) & + \\
Dorcadospyris alata (Down-hole contamination ?) & + \\
\hline
\end{tabular}

Core 4 contains abundant diatoms, with a few wellpreserved radiolarians which are sufficient for age assignment. The presence of $C$. tetrapera, E. diaphanes, $C$. cornuta, $S$. delmontensis, and $C$. prismaticus suggests an early Miocene age ( $S$. delmontensis Zone). In Core 5 the coarse fraction (calcite-free) is principally sponge spicules; rare radiolarians of late Oligocene age $(D$. ateuchus Zone) are present, including D. ateuchus and D. papilio.

Cores 6 through 9 contain very poorly preserved fragments of middle to late Eocene age, including the genera Theocampe, Lithocyclia, and Stylosphaera. Core 10 belongs to the middle Eocene $T$. triacantha Zone, based on the presence of $P$. dorus, E. lagena, $T$. 
mongolfieri, and L. ocellus. Core 12 is of lowermost middle Eocene age, based on rare specimens of $T$. amphora and one specimen resembling the early morphotype of $T$. mongolfieri. Numerous poorly preserved spongidiscids were also observed in Core 12, but none were sufficiently preserved for exact identification. No identifiable radiolaria were observed in core catcher samples from below Core 12 .

\section{DISCUSSION}

\section{Radiolarian Biostratigraphy of Sierra Leone Rise: Comparison with Stratigraphic Sequences in Other Tropical and Subtropical Regions}

Previous legs of the Deep Sea Drilling Project have recovered sufficient sequences of radiolarian-bearing sediment to allow the construction of a Cenozoic radiolarian zonation for the tropical oceans. This zonation has been based largely on detailed studies of sections from the Caribbean (Leg 4; see Riedel and Sanfilippo, 1970), the equatorial Pacific (Leg 7; see Riedel and Sanfilippo, 1971), and the Gulf of Mexico (Leg 10; see Foreman, 1973; Sanfilippo and Riedel, 1973). Subsequent studies in the tropical Pacific (Moore, 1971; Dinkelman, 1973; and Johnson, 1976) and in the tropical Indian Ocean (Johnson, 1974; Nigrini, 1974) suggest that this zonation may be generally applicable in tropical and subtropical latitudes.

It is perhaps useful to make some preliminary comparisons of the biostratigraphic succession at Site $366 / 366$ A with the sequence of radiolarian "events" established previously, and summarized by Riedel and Sanfilippo (1974). These comparisons must be regarded as tentative since many of the differences in occurrences of diagnostic taxa may be due either to problems of species abundance and preservation, or to differences among the various investigators as to the morphologic limits placed upon a given taxon. Nevertheless these preliminary observations, if sufficiently refined by subsequent study, may eventually be interpretable in terms of faunal provinciality and paleobiogeography.

\section{Miocene}

There are several species belonging to the genus Calocycletta which are represented in the lower and middle Miocene of tropical regions. Moore (1972) has identified and described six species, and has suggested a phylogenetic relationship between them. Of these six species, only three $(C$. costata, $C$. virginis, $C$. robusta) were identified in the material from Site 366 . The stratigraphic ranges of these thres taxa are clearly defined at Site 366 , and are consistent with the ranges established in other tropical successions. The remaining three species $(C$. serrata, $C$. caepa, $C$. parva) were not identified in any of the Site 366 material.

Three species of the Cannartus-Ommatartus lineage (C. violina, C. tubarius, C. prismaticus) are well represented at Site 366. The morphotypes of each form have fairly well defined stratigraphic ranges which are consistent with those established elsewhere. C. prismaticus, however, has a poorly defined upper limit; co-occurrences of this morphotype with those of successive taxa in the lineage are common. C. bassanii, which is common in Mediterranean regions (Sanfilippo et al., 1973), was represented only in scattered and rare occurrences at Site 366.

Carpocanopsis bramlettei and C. cingulatum are relatively rare, and their upper ranges are poorly defined because of poor preservation of material in the $D$. alata Zone and above. The upper limit of $C$. cristatum at Site 366 is apparently within the $S$. wolfii Zone, which is significantly lower than that established elsewhere.

Taxa belonging to the collosphaerid family are notably rare at Site 366 compared with other tropical regions.

Species of the Cyclampterium lineage (Sanfilippo and Riedel, 1970) are rare. The $C$. pegetrum to $C$. leptetrum transition is not well defined, but its approximate position is consistent with previous results.

Cyrtocapsella japonica and C. elongata are notably rare or absent entirely at Site 366. C. cornuta is common with a well-defined upper limit. This limit is comparable to that observed in the Indian Ocean (Johnson, 1974), but somewhat earlier than that of the tropical Pacific (e.g., Riedel and Sanfilippo, 1971; Johnson, 1976). C. tetrapera is relatively rare, and has a significantly more restricted range at Site 366 than elsewhere.

Three species of Dorcadospyris (D. ateuchus, D. alata, $D$. dentata) have stratigraphic ranges at Site 366 which are clearly defined and in agreement with previous interpretations. D. simplex and D. forcipata are relatively common in the lower Miocene zones, but their lower and upper limits are poorly defined, and their stratigraphic value is uncertain. A form closely resembling $D$. papilio occurs in the upper Oligocenelower Miocene, but it differs from the earlier descriptions of the taxon in that the angle of divergence of the feet from the central capsule is more nearly horizontal than upward, thereby yielding a less pronounced curvature to the feet. In spite of the relatively good control on the stratigraphic ranges of some of the morphotypes in this genus, the phylogenetic relationships of the genus are not yet well understood.

Species of Lithopera are notably absent, perhaps as a consequence of increasingly poor preservation upward within the middle Miocene material.

Lychnocanoma elongata is common with a very well defined first appearance, but with a somewhat shorter stratigraphic range than that observed elsewhere.

Stichocorys delmontensis is common at Site 366 with a well-defined lower limit. S. armata is virtually absent, and may therefore be more indicative of Mediterranean affinities and latitudes (see Sanfilippo et al., 1973). S. wolffii is relatively rare, but its lower limit is sufficiently definitive to be a reliable zonal boundary.

Theocorys spongoconum is relatively rare with only scattered occurrences, and is of doubtful stratigraphic value in the tropical Atlantic.

Theocyrtis annosa is common, well preserved, and has a very well defined upper limit which is satisfactory for defining the base of the $S$. delmontensis Zone as proposed by Riedel and Sanfilippo (1974). 


\section{Oligocene}

Artophormis gracilis is common and consistently present in all samples throughout its stratigraphic range, though the lower meshwork (as described initially by Riedel, 1959) is generally missing from most of the specimens examined. A. barbadensis has only scattered and rare occurrences, and is of doubtful stratigraphic value.

Species of the genus Cyclampterium are virtually absent from the lower Oligocene section.

Dorcadospyris ateuchus is common with a stratigraphically useful first appearance. $D$. papilio has a poorly defined lower limit, and its relationship to similar forms (D. circulus, D. forcipata) is unclear. $D$. triceros has only scattered occurrences, and the proposed $D$. triceros to $D$. ateuchus transition is not well defined.

Histiastrum martinianum has been reported for the Mediterranean region (Sanfilippo et al., 1973), but is not reported in DSDP samples from the tropical Pacific or Indian Oceans. At Site 366 its stratigraphic range spans the entire Oligocene and part of the upper Eocene. Its upper limit may be a useful stratigraphic indicator, although it corresponds approximately with several other radiolarian "events."

Lithocyclia angustum is virtually absent from the Oligocene material at Site 366 , and consequently the base of the T. tuberosa zone can only be approximated on the basis of the disappearance of $L$. aristotelis and several other common upper Eocene forms (see Table 1C). L. aristotelis has scattered occurrences above the level estimated to be the base of the T. tuberosa Zone, but its abundance decreases markedly above this zonal boundary. $L$. crux has scattered and rare occurrences in the bottom half of the $T$. tuberosa Zone.

Theocyrtis annosa is common at Site 366 , and has a well-defined first appearance in the lower $D$. ateuchus Zone. There is a considerable stratigraphic interval between the disappearance of $T$. tuberosa and the appearance of $T$. annosa, so the evolutionary relationship between these two forms at Site 366 is not at all clear. T. tuberosa shows a sharply defined upper limit. Studies of material from the tropical Indian Ocean (Johnson, 1974) suggest that $T$. tuberosa may have evolved into a smoother-shelled form resembling Calocycletta acanthocephala (see Petrushevskaya and Kozlova, 1972). There is no evidence of this smoothershelled form in the Oligocene at Site 366, although such a form does co-occur with $T$. tuberosa in the underlying upper Eocene material (Table 1C).

\section{Eocene}

The middle and upper Eocene assemblages at Site 366 are quite diverse, though preservation ranges from good to very poor. While the occurrences of taxa shown in Table 1C are based on a thorough examination of each slide, no attempt was made to search thoroughly for each taxon in each slide. Consequently the actual stratigraphic ranges of some of the taxa may be somewhat longer than those shown in Table 1C.
Specimens of Anthocyrtoma sp. are rare and scattered, and are insufficiently abundant to be of stratigraphic value.

The transition from Calocyclas hispida to C. turris is well defined near the base of the T. bromia Zone, and is a relatively good stratigraphic indicator. $C$. asperum (see Petrushevskaya and Kozlova, 1972) occurs in a few samples near the Eocene/Oligocene boundary. However its relationship to $C$. turris or other forms is uncertain, and its stratigraphic value in the tropical Atlantic is doubtful.

Calocycletta acanthocephala is probably of stratigraphic value, but more work is required to establish its relationship to other related forms (e.g., T. tuberosa).

Carpocanistrum azyx has well defined lower and upper limits within the lower T. bromia Zone, and is a reliable stratigraphic indicator.

Dorcadospyris triceros spans the entire $T$. bromia Zone. Its first appearance is poorly defined because of poor specimen preservation, but appears to be near the base of the $T$. bromia Zone.

Eusyringium fistuligerum and $E$. lagena are both reliable stratigraphic indicators at Site 366 , although there is significant overlap between the morphotypes in the transition interval between the two forms.

Lithocyclia vespertilio disappears within the $P$. chalara Zone at Site 366, which is consistent with previous interpretations (Sanfilippo and Riedel, 1973; Foreman, 1973). The transition from $L$. archaea to $L$. vespertilio within the $T$. mongolfieri Zone agrees with earlier interpretations, but is poorly defined due to poor sample preservation.

The Lithocyclia ocellus to $L$. aristotelis transition occurs at the base of the T. bromia Zone in DSDP Leg 10 material (Sanfilippo and Riedel, 1973). However, the Site 366 material shows an overlap between the two morphotypes which spans at least the lower half of the T. bromia Zone.

Phormocyrtis embolum has a fairly well defined upper limit near the $P$. chalara/P. goetheana zonal boundary. It is consistently present in the poorly preserved middle Eocene material. Its last occurrence is probably a very good stratigraphic indicator; this should be documented in other sequences with better preservation and a thicker $P$. chalara zone.

The species of Podocyrtis which are stratigraphically significant in defining zonal boundaries $(P$. goetheana, $P$. chalara, $P$. mitra, $P$. ampla) have well-defined first appearances at Site 366 in spite of poor sample preservation. Podocyrtis diamesa, $P$. papalis, and $P$. sinuosa show only scattered occurrences, and their stratigraphic limits are not well defined. These limits could perhaps be defined with more work, although the relatively poor preservation of material at Site 366 makes the value of such an effort doubtful.

Rhopalocanium ornatum disappears in the $P$. goetheana zone at Site 366, a level slightly younger than that identified previously (Foreman, 1973; Sanfilippo and Riedel, 1973). Its last occurrence is probably a reliable "event".

Species of Theocampe are common at Site 366, and dominate the assemblages in the relatively poorly 
preserved material of Eocene age. T. pirum is restricted to the $T$. bromia zone, $T$. mongolfieri is present in scattered occurrences extending down to the base of the $T$. mongolfieri zone, and T. amphora is present throughout the upper and middle Eocene sections. These ranges are consistent with those previously established. Other species ( $T$. armadillo, $T$. urceolus) have poorly defined lower limits.

Theocyrtis tuberosa is consistently present in upper Eocene samples, and shows a well-defined lower boundary in the lower part of the $T$. bromia zone.

Thyrsocyrtis bromia is common within a limited stratigraphic interval in the lower part of the $T$. bromia Zone at Site 366. T. tetracantha and T. triacantha have first occurrences which are in agreement with previous results (Sanfilippo and Riedel, 1973; Foreman, 1973). However, at Site 366 these two species co-occur throughout the stratigraphic range of $T$. tetracantha, and the two disappear at the same level in the middle part of the $T$. bromia zone. Consequently the evidence from Site 366 does not clearly point to the evolution of $T$. tetracantha from $T$. triacantha.

\section{Regional Variations in Silica Accumulation and Microfossil Preservation}

At each of the sites drilled on Leg 41, radiolaria are virtually absent in much of the late Neogene and early Paleogene material. The considerable geographic area represented by these sites suggests that the similarity in silica accumulation patterns may have significant regional paleooceanographic implications.

The following table, based on radiolarian investigations reported in this chapter, documents the virtual absence of biogenic silica from the Neogene sediments off northwest Africa.

\begin{tabular}{|c|c|c|c|c|}
\hline Site & Latitude & $\begin{array}{l}\text { Thickness } \\
\text { of Siliceous } \\
\text { Late } \\
\text { Pleistocene } \\
\text { Sediment } \\
\text { (m) }\end{array}$ & $\begin{array}{l}\text { Thickness } \\
\text { of Non- } \\
\text { Siliceous } \\
\text { Interval } \\
\text { (m) }\end{array}$ & $\begin{array}{l}\text { Age of Underlying } \\
\text { Siliceous Interval }\end{array}$ \\
\hline 366 & $05^{\circ} 40^{\prime} \mathrm{N}$ & $\sim 16$ & $\sim 132$ & $\begin{array}{l}\text { Middle Miocene } \\
\text { (D. alata Zone) }\end{array}$ \\
\hline 367 & $12^{\circ} 29^{\prime} \mathrm{N}$ & $\sim 10$ & $\sim 300$ & $\begin{array}{l}\text { Late Eocene } \\
\text { (T. bromia Zone) }\end{array}$ \\
\hline 368 & $17^{\circ} 30^{\prime} \mathrm{N}$ & $\sim 20$ & $\sim 215$ & $\begin{array}{l}\text { Early Miocene } \\
\text { (C. costata Zone) }\end{array}$ \\
\hline 369 & $26^{\circ} 35^{\prime} \mathrm{N}$ & $\sim 5$ & $\sim 50$ & $\begin{array}{l}\text { Middle Miocene } \\
\text { (C. petterssoni Zone) }\end{array}$ \\
\hline 370 & $32^{\circ} 50^{\prime} \mathrm{N}$ & $<5$ & $\sim 210$ & $\begin{array}{l}\text { Early Miocene } \\
\text { (S. wolffii Zone) }\end{array}$ \\
\hline
\end{tabular}

At each of these five sites, there is a substantial thickness of silica-poor sediment beneath a thin layer of radiolarian-bearing late Pleistocene material. The silica-poor intervals begin well above the Pliocene/Pleistocene boundary (determined by other microfossil groups), and extend down at least as far as the middle or early Miocene. Comparable results indicating silica-deficient Neogene sediments were also obtained at Sites 139-141 (DSDP Leg 14; see Petrushevskaya and Kozlova, 1972), although close comparison is not possible because of relatively incomplete coring at the Leg 14 sites.
These observations indicate that much of the ocean floor off northwest Africa was not receiving siliceous skeletal material during an interval of approximately 15 m.y. in the late Neogene. Evidently the present-day locations of the zones of upwelling and high productivity in the tropical Atlantic and near northwest Africa do not correspond with the positions of these zones during most of the late Neogene. A more precise documentation of this proposed shift in circulation characteristics during the late Pleistocene requires a more extensive examination of the Neogene depositional record over a wide geographic region within the tropical Atlantic.

The relative absence of radiolarians from Paleocene and early Eocene material at Sites 366, 369, and 370 may have a similar paleoclimatic explanation, or alternatively may be explained in terms of diagenetic processes. The increasingly poorer preservation of the radiolarian assemblages with depth in the Eocene sediments strongly suggests a diagenetic alteration of the siliceous skeletal material. Examination of the coarse fractions of samples before acid treatment failed to identify more than trace amounts of calcified or pyritized radiolarian tests, suggesting that perhaps siliceous sedimentation did not occur in this region during the earliest Cenozoic. However, special preparation procedures applied to porcellanite layers in material from Site 368 extracted significant quantities of identifiable radiolarians (see Appendix of this report). Consequently an alternative possibility is that silica was indeed deposited during the early Paleogene, but that diagenetic effects caused remobilization of the silica and segregation into porcellanite and chert layers.

\section{LIST OF SPECIES}

The purpose of this listing is to provide bibliographic references to the taxa mentioned in this report and in the accompanying tables. When the published literature contains several different concepts of the limits of a species, the reference cited conforms to the concept as applied here. For each species, at least one recent reference is given which contains appropriate species descriptions and illustrations, thereby enabling the reader to determine the criteria which have been applied in identifying the taxa in this report.

The appendix of this report includes a more expanded taxonomic section (by Helen P. Foreman) discussing several forms identified in the early Paleogene material at Site 368 .

Amphicraspedum prolixum Sanfilippo and Riedel, 1973, p. 524 , pl. 28 , fig. $3 ; 4$.

Amphirhopalum ypsilon Haeckel, 1887, p. 522; Nigrini, 1967, p. 35 , pl. 3, fig. 3a-d.

Anthocyrtidium angulare Nigrini, 1971, p. 445 , pl. 34.1 , fig. 3a, b. Anthocyrtoma sp., Riedel and Sanfilippo, 1970, p. 524, pl. 6, fig. 2, 3.

Artophormis barbadensis (Ehrenberg); Riedel and Sanfilippo, 1970, p. 532 , pl. 13 , fig. 5 .

Artophormis gracilis Riedel, 1959, p. 300, pl. 2, fig. 12, 13; Riedel and Sanfilippo, 1970, p. 532, pl. 13, fig. 6, 7 .

Axoprunum angelinum (Campbell and Clark); Kling, 1973, p. 534 pl. 1, fig. 13-16; pl. 6, fig. 14-18.

Bekomiforma mynx Sanfilippo and Riedel, 1974, p. 1020, pl. 2, fig. 3-5.

Buryella clinata Foreman, 1973, p. 433, pl. 9, fig. 19.

Buryella tetradica Foreman, 1973, p. 433, pl. 9, fig. 13, 14.

Calocyclas asperum (Ehrenberg); Petrushevskaya and Kozlova, 1972, p. 548 , pl. 28 , fig. $16-18$.

Calocyclas hispida (Ehrenberg); Foreman, 1973, p. 434, pl. 1, fig. 12-15.

Calocyclas turris Ehrenberg; Foreman, 1973, p. 434; Riedel and Sanfilippo, 1970, pl. 13, fig. 3, 4 .

Calocycletta acanthocephala (Ehrenberg); Petrushovskaya and Kozlova, 1972, p. 544, pl. 35, fig. 5-7. 
Calocycletta caepa Moore, 1972, p. 150, pl. 2, fig. 4-7.

Calocycletta costata (Riedel), Riedel and Sanfilippo, 1970, p. 535, pl. 14, fig. 12; Moore, 1972, p. 147, pl. 1, fig. 8.

Calocycletta robusta Moore, 1971, p. 743, pl. 10, fig. 5, 6; 1972 , p. 148, pl. 1, fig. 6 .

Calcocycletta serrata Moore, 1972, p. 148, pl. 2, fig. 1-3.

Calocycletta virginis (Haeckel), Riedel and Sanfilippo, 1970, p. 535, pl. 14, fig. 10; Moore, 1972, p. 147, pl. 1, fig. 7.

Calocycloma ampulla (Ehrenberg); Foreman, 1973, p. 434, pl. 9, fig. 20.

Calocycloma castum (Haeckel), Foreman, 1973, p. 434, pl. 1, fig. 7, 9, 10.

Cannartus bassanii (Carnevale), Sanfilippo et al., 1973, p. 216, pl. 1, fig. 1-3.

Cannartus laticonus Riedel, 1959, p. 291, pl. 1, fig. 5; Riedel and Sanfilippo, 1971, pl. 1C, fig. 13.

Cannartus mammiferus (Haeckel), Riedel, 1959, p. 291, pl. 1, fig. 4.

Cannartus (?) petterssoni Riedel and Sanfilippo, 1970, p. 520, pl. 14, fig. 3; 1971, pl. 1c, fig. 19, 20.

Cannartus prismaticus (Haeckel), Riedel and Sanfilippo, 1970, p. 520, pl. 15, fig. 1; 1971, p. 1588, pl. 2C, fig. 11-13.

Cannartus tubarius (Haeckel), Riedel and Sanfilippo, 1970, p. 520, pl. 15, fig. 2; Kling, 1971, pl. 3, fig. 3 .

Cannartus violina Haeckel, 1887, p. 358; Riedel, 1959, p. 290, pl. 1, fig. 3; Moore, 1971, pl. 12, fig. 4.

Carpocanistrum azyx Sanfilippo and Riedel, 1973, p. 530, pl. 35, fig. 9.

Carpocanopsis bramlettei Reidel and Sanfilippo, 1971, p. 1597, pl. $2 \mathrm{G}$, fig. $8-14$; pl. 8 , fig. 7 .

Carpocanopsis cingulatum Riedel and Sanfilippo, 1971, p. 1597, pl. 2G, fig. 17-21, pl. 8, fig. 8 .

Carpocanopsis cristatum (Carnevale)?, Riedel and Sanfilippo, 1971, p. 1957, pl. 1G, fig. 16; pl. 2G, fig. 1-7.

Carpocanopsis favosum (Haeckel), Riedel and Sanfilippo, 1971, p. 1957, pl. 2G, fig. 15, 16; pl. 8, fig. 9-11.

Centrobotrys petrushevskayae Sanfilippo and Riedel, 1973, p. 532, pl. 36 , fig. 12,13 .

Clathrocanium sphaerocephalum Haeckel; Sanfilippo et al., 1973, pl. 4 , fig. 9.

Clathrocorona atreta Sanfilippo and Riedel; Sanfilippo et al., 1973. p. 219 , pl. 4, fig. 5-8.

Clathrocycloma parcum Foreman, 1973, p. 434, pl. 11, fig. 12.

Cryptoprora ornata Ehrenberg; Sanfilippo and Riedel, 1973, pl. 35, fig. 3,4 .

Cyclampterium (?) leptetrum Sanfilippo and Riedel, 1970, p. 456, pl. 2, fig. 11, 12; Riedel and Sanfilippo, 1971, pl. 2D, fig. 9-12.

Cyclampterium (?) milowi Riedel and Sanfilippo, 1971, p. 1593, pl. 3B, fig. 3; pl. 7, fig. 8, 9; Sanfilippo et al., 1973, pl. 220, pl. 4 , fig. $12-14$.

Cyclampterium (?) pegetrum Sanfilippo and Riedel, 1970, p. 456, pl. 2, fig. 8-10; Riedel and Sanfilippo, 1971, pl. 2D, fig. 13, 14; pl. 3B, fig. 1, 2.

Cyrtocapsella cornuta Haeckel, Sanfilippo and Riedel, 1970, p. 453, pl. 1, fig. 19, 20; Sanfilippo et al., 1973, pl. 5, fig. 1, 2.

Cyrtocapsella elongata (Nakaseko), Sanfilippo and Riedel, 1970, p. 452 , pl. 1, fig. 11,12 .

Cyrtocapsella japonica (Nakaseko), Sanfilippo and Riedel, 1970, p. 452, pl. 1, fig. 13-15; Sanfilippo et al., 1973, pl. 5, fig. 3.

Cyrtocapsella tetrapera Haeckel; Sanfilippo and Riedel, 1970, p. 453, pl. 1, fig. 16-18; Sanfilippo et al., 1973, pl. 5, fig. 4-6.

Dendrospyris bursa Sanfilippo and Riedel, Sanfilippo et al., 1973, p. 217 , pl. 2, fig. 9-13.

Dicolocapsa microcephala Haeckel, 1887, p. 1312; Sanfilippo and Riedel, 1970, pl. 1, fig. 7.

Dorcadospyris alata (Riedel), Riedel and Sanfilippo, 1970, pl. 14, fig. 5; 1971, pl. 2D, fig. 1; Moore, 1971, pl. 11, fig. 3, 4.

Dorcadospyris ateuchus (Ehrenberg), Riedel and Sanfilippo, 1970, pl. 15, fig. 4 ; 1971, p. 1590 , pl. 2D, fig. 6, pl. 3A, fig. 9, 10.

Dorcadospyris circulus (Haeckel), Moore, 1971, p. 739, pl. 8, fig. 35.

Dorcadospyris dentata (Haeckel), 1887, p. 1037; Riedel, 1957, p. 79, pl. I, fig. 3.

Dorcadospyris forcipata (Haeckel), Moore, 1971, p. 740, pl. 10, fig. I, 2.

Dorcadospyris papilio (Riedel), Riedel and Sanfilippo, 1970, p. 523, pl. 15, fig. 5; Moore, 1971, p. 739, pl. 8, fig. 6, 7 .

Dorcadospyris quadripes Moore, 1971, p. 738, pl. 7, fig. 3-5.
Dorcadospyris simplex (Riedel); Riedel and Sanfilippo, 1970, pl. 15, fig. 6 .

Dorcadospyris spinosa (Moore, 1971, p. 739, pl. 7, fig. 1, 2.

Dorcadospyris triceros (Ehrenberg); Moore, 1971, p. 739, pl. 6, fig. 1-3.

Eucyrtidium acuminatum (Ehrenberg); Nigrini, 1967, p. 81, pl. 8, fig. $3 a-b$

Eucyrtidium calvertense Martin; Hays, 1970, p. 213, pl. 1, fig. 6.

Eurcyrtidium cienkowskii Haeckel, 1887, p. 1493; Sanfilippo et al., 1973, p. 221, pl. 5, fig. 7-11.

Eucyrtidium diaphanes Sanfilippo and Riedel; Sanfilippo et al., 1973, p. 221, pl. 5, fig. 12-14.

Eusyringium fistuligerum (Ehrenberg), Riedel, 1957, p. 94, pl. 4, fig. 8; Riedel and Sanfilippo, 1970, p. 527, pl. 8, fig. 8, 9; Foreman, 1973, p. 435 , pl. 11, fig. 6.

Eusyringium lagena (Ehrenberg); Riedel and Sanfilippo, 1970, p. 527, pl. 8, fig. 5-7; Foreman, 1973, p. 435 , pl. 11, fig. 4, 5.

Histiastrum martinianum Carnevale group; Sanfilippo et al., 1973, p. 217 , pl. 2 , fig. 7,8 .

Lamprocyclas maritalis maritalis Haeckel; Nigrini, 1967, p. 74, pl. 7, fig. 5.

Lamprocyclas maritalis polypora Nigrini, 1967, p. 76, pl. 7, fig. 6 .

Lamprocyrtis (?) hannai (Campbell and Clark); Kling, 1973, p. 638, pl. 5 , fig. $12-14$; pl. 12 , fig. $10-14$.

Lamprocyrtis haysi Kling, 1973, p. 639, pl. 15, fig. 1-3.

Lithochytris archaea Riedel and Sanfilippo, 1970 , p. 528, pl. 9, fig. 7; Foreman, 1973, p. 436, pl. 2, fig. 4, 5.

Lithochytris vespertilio Ehrenberg; Riedel and Sanfilippo, 1970, p. 528 , pl. 9 , fig. 8,9 .

Lithocyclia angustum (Riedel), Riedel and Sanfilippo, 1970, p. 522, pl. 13, fig. 1, 2; 1971, pl. 3A, fig. 1, 3 .

Lithocyclia aristotelis (Ehrenberg) group, Riedel and Sanfilippo, 1970 , p. 522; 1971, pl. 3A, fig. 4, 5.

Lithocyclia crux Moore, 1971, p. 737, pl. 6, fig. 4.

Lithocyclia ocellus Ehrenberg group; Riedel and Sanfilippo, 1970, p. 522 , pl. 5, fig. 1,2 .

Lithomitra docilis Foreman, 1973, p. 431, pl. 8, fig. 20-22; pl. 9, fig. 3-5.

Lithopera bacca Ehrenberg; Nigrini, 1967, p. 54, pl. 6, fig. 2; Sanfilippo and Riedel, 1970, p. 455, pl. 1, fig. 29.

Lithopera baueri Sanfilippo and Riedel, 1970, p. 455, pl. 2, fig. 1, 2.

Lithopera neotera Sanfilippo and Riedel, 1970, p. 454, pl. 1, fig. 24$26,28$.

Lithopera renzae Sanfilippo and Riedel, 1970, p. 454, pl. 1, fig. 21$23,27$.

Lithopera thornburgi Sanfilippo and Riedel, 1970, p. 455, pl. 2, fig. 4-6.

Lophocyrtis biaurita (Ehrenberg); Foreman, 1973, p. 442, pl. 8, fig. 23-26.

Lophocyrtis (?) jacchia (Ehrenberg); Riedel and Sanfilippo, 1971, p. 1594 , pl. 3C, fig. 4,5 , pl. 7 , fig. 16.

Lychnocanoma babylonis (Clark and Campbell) group; Foreman, 1973 , p. 437 , pl. 2 , fig. 1.

Lychnocanoma bellum (Clark and Campbell); Foreman, 1973, p. 437, pl. 11, fig. 9.

Lychnocanoma elongata (Vinassa), Sanfilippo et al., 1973, p. 221, pl. 5, fig. 19, 20.

Lychnodictyum audax Riedel, 1953, p. 810, pl. 85, fig. 9; Sanfilippo and Riedel, 1974, p. 1022, pl. 2, fig. 8.

Ommatartus tetrathalamus (Haeckel), Riedel and Sanfilippo, 1971, p. 1588, pl. IC, fig. 5-7.

Phormocyrtis embolum (Ehrenberg); Riedel, 1957, p. 88, pl. 3, fig. 6, 7; Nigrini, 1974, pl. 1H, fig. 4, 5.

Phormocyrtis striata striata Brandt; Foreman, 1973, p. 438, pl. 7, fig. $5,6,9$.

Phormocyrtis striata exquisita (Kozlova); Foreman, 1973, p. 438, pl. 12 , fig. 5 .

Phormocyrtis turgida (Krashenennikov); Foreman, 1973, p. 438, pl. 7 , fig. 10 ; pl. 12 , fig. 6 .

Phormostichoartus corona (Haeckel); Riedel and Sanfilippo, 1971, p. 1600 , pl. 11, fig. 13-15; pl. 2J, fig. 1-5.

Podocyrtis coronatus (Ehrenberg); Petrushevskaya and Kozlova, 1972 , p. 543 , pl. 35 , fig. 3.

Podocyrtis (Lampterium) chalara Riedel and Sanfilippo, 1970, p. 535, pl. 12, fig. 2, 3 .

Podocyrtis (Lampterium) goetheana (Haeckel), Riedel and Sanfilippo, 1970 , p. $535 ; 1971$, pl. 8 , fig. 13 . 
Podocyrtis (Lampterium) mitra (Ehrenberg), Riedel and Sanfilippo, 1970 , p. 534, pl. 11, fig. 5, 6.

Podocyrtis (Lampterium) sinuosa Ehrenberg (?), Riedel and Sanfilippo, 1970, pl. 11, fig. 3, 4.

Podocyrtis (Podocyrtis) ampla Ehrenberg, Riedel and Sanfilippo, 1970 , p. 533 , pl. 12, fig. $7,8$.

Podocyrtis (Podocyrtis) ampla fasciolata Nigrini, 1974, p. 1069. pl. IK, fig. 1, 2.

Podocyrtis (Podocyrtis) diamesa Riedel and Sanfilippo, 1970, p. 53, pl. 12, fig. 4; Sanfilippo and Riedel, 1973, p. 531, pl. 20, fig. 9, 10 ; pl. 35, fig. 10, 11.

Podocyrtis papalis Ehrenberg, 1874, fig. 2; 1874, p. 251; Riedel and Sanfilippo, 1970, p. 533, pl. 11, fig. 1; Sanfilippo and Riedel, 1973, pl. 20, fig. 11-14; pl. 36, fig. 2, 3 .

Pterocanium praetextum (Ehrenberg), Riedel, 1957, p. 86, pl. 3, fig. 1-3; Moore, 1971, pl. 13, fig. 3.

Pterocanium trilobum (Haeckel); Nigrini, 1967, p. 71, pl. 7, fig. 3a, b.

Rhopalocanium ornatum Ehrenberg, 1847, fig. 3; 1854, pl. 36, fig. 9; 1874 , p. 256 ; 1876 , p. 82 , pl. 17 , fig. 8 ; Foreman, 1973 , p. 439 , pl. 2 , fig. $8-10$; pl. 12 , fig. 3 .

Sethochytris triconiscus Haeckel; Riedel and Sanfilippo, 1970, p. 528, pl. 9, fig. 6.

Siphocampe corbula (Harting), Riedel and Sanfilippo, 1971, p. 6101, pl. $1 \mathrm{H}$, fig. 18-25.

Spongaster tetras Ehrenberg, 1860, p. 833; Nigrini, 1967, p. 41, pl. 5, fig. 1a, b, 2 .

Stichocorys armata (Haeckel), Riedel and Sanfilippo, 1971, p. 5195, pl. 2E, fig. 13-15; Sanfilippo et al., 1973, p. 222, pl. 6, fig. 1, 2.

Stichocorys delmontensis (Campbell and Clark), Sanfilippo and Riedel, 1970, p. 451, pl. 1, fig. 9; Riedel and Sanfilippo, 1971, pl. $1 \mathrm{~F}$, fig. $5-7$; pl. $2 \mathrm{E}$, fig. 10,11 .

Stichocorys diploconus (Haeckel); Sanfilippo and Riedel, 1970, p. 451 , pl. 1, fig. 31,32 .

Stichocorys peregrina (Riedel), Riedel and Sanfilippo, 1970, p. 530; 1971 , pl. 8 , fig. 5 .

Stichocorys wolffii Haeckel, 1887, p. 1479; Riedel, 1954, p. 173, pl. 1, fig. 4; Riedel, 1957, p. 92, pl. 4, fig. 6, 7; Riedel and Sanfilippo, 1971, pl. 2E, fig. 8, 9.

Stylosphaera coronata coronata Ehrenberg; Sanfilippo and Riedel, 1973, p. 520, pl. 1, fig. 13-17; pl. 25, fig. 4.

Stylosphaera coronata laevis Ehrenberg; Sanfilippo and Riedel, 1973, p. 520 , pl. 1, fig. 19 ; pl. 25, fig. 5-6.

Stylosphaera coronata sabaca Sanfilippo and Riedel, 1973, p. 521, pl. I, fig. 18; pl. 25, fig. 7, 8 .

Thecosphaerella rotunda (Borisenko); Sanfilippo and Riedel, 1973, p. 522 , pl. 3 , fig. $7-11$; pl. 26 , fig. 3 .

Theocampe amphora (Haeckel) group, Foreman, 1973, p. 431, pl. 8, fig. 7, 9-13; pl. 9, fig. 8,9 .

Theocampe armadillo (Ehrenberg) group, Riedel and Sanfilippo, 1971, p. 1601, pl. 3E, fig. 3-6.

Theocampe mongolfieri (Ehrenberg), Burma, 1959, p. 239; Riedel and Sanfilippo, 1970, p. 536, pl. 12, fig. 9; Foreman, 1973, p. 432, pl. 8 , fig. 1 ; pl. 9 , fig. 17 .

Theocampe pirum (Ehrenberg), Riedel and Sanfilippo, 1971, p. 1601, pl. $3 \mathrm{E}$, fig. 10, 11; Foreman, 1973, pl. 9, fig. 11, 12.

Theocampe urceolus (Haeckel), Foreman, 1973, p. 432, pl. 8, fig. 14. 17; pl. 9, fig. 6, 7.

Theocapsomma sp., Foreman, 1968, p. 29; Petrushevskaya and Kozlova, 1972 , p. 535 , pl. 22 , fig. 1-3.

Theocorys spongoconum Kling, 1971, p. 1087, pl. 5, fig. 6; Riedel and Sanfilippo, 1971, pl. 2F, fig. 4, pl. 3C, fig. 3.

Theocorythium trachelium (Ehrenberg), Nigrini, 1967, p. 79, pl. 8, fig. 2.

Theocorythium vetulum Nigrini, 1971, p. 447, pl. 34.1, fig. 6 a-b.

Theocotyle cryptocephala cryptocephala (Ehrenberg); Foreman, 1973, p. 440 , pl. 4 , fig. 6,$7 ;$ pl. 12 , fig. 18 .

Theocotyle ficus (Ehrenberg); Foreman, 1973, p. 441, pl. 4, fig. 1620.

Theocotyle venezuelensis Riedel and Sanfilippo, 1970, p. 525, pl. 6, fig. 9-10; Foreman, 1973, p. 440, pl. 4, fig. 12.

Theocyrtis annosa (Riedel), Riedel and Sanfilippo, 1970, p. 535, pl. 15, fig. 9.

Theyrtis tuberosa Riedel, 1959, p. 258, pl. 2, fig. 10, 11; Moore, 1971 , p. 743 , pl. 5 , fig. 5,6 .

Thyrsocyrtis bromia Ehrenberg, 1874 , p. 260 ; 1876, p. 84, pl. 12, fig. 2; Riedel and Sanfilippo, 1970, p. 526; 1971, pl. 8, fig. 6; Moore, 1971, pl. 5, fig. 1-3.
Thyrsocyrtis hirsuta robusta Riedel and Sanfilippo, 1970, p. 526, pl. 8, fig. 1; Foreman, 1973, p. 442, pl. 3, fig. 17.

Thyrsocyrtis hirsuta tensa Foreman, 1973, p. 442, pl. 3, fig. 13-16; pl. 12 , fig. 8 .

Thyrosocyrtis rhizodon Ehrenberg, 1876, p. 94, pl. 12, fig. 1; Riedel and Sanfilippo, 1970, p. 525, pl. 7, fig. 6, 7; Foreman, 1973, p. 442 , pl. 3 , fig. $1,2$.

Thyrsocyrtis tetracantha (Ehrenberg), Riedel and Sanfilippo, 1970, p. 527; Moore, 1971, pl. 4, fig. 3.

Thyrsocyrtis triacantha (Ehrenberg), Riedel and Sanfilippo, 1970, p. 526, pl. 8, fig. 2, 3; Foreman, 1973, p. 442, pl. 12, fig. 9-11.

\section{ACKNOWLEDGMENTS}

I thank the DSDP curatorial staff at Lamont-Doherty Geological Observatory for supplying supplementary samples. Special thanks are due to Helen P. Foreman for examining the Paleogene material at Site 368, described in the Appendix of this report. W.R. Riedel, A. Sanfilippo, and C. Nigrini contributed useful discussions and assistance in the identification of several radiolarian specimens. Financial support for this investigation was provided under NSF Grants OCE72-01715 (to DAJ) and OCE75-19288 (to Helen P. Foreman). This is Woods Hole Oceanographic Institution Contribution 3822 .

\section{REFERENCES}

Brandt, R., 1935. Radiolarien. In Wetzel, O. Die Mikropaläontologie des Heiligenhafener Kieseltones (Ober-Eozän): Niedersächs. Geol. Vereins, Jahresber, v. 27 , p. $48-74$.

Burma, B.H., 1959. On the status of Theocampe Haeckel, and certain similar genera: Micropaleontology, v. 5, p. 325330.

Dinkelman, M.G., 1973. Radiolarian stratigraphy: Leg 16, Deep Sea Drilling Project. In van Andel, T.H., Heath, G.R., et al., Initial Reports of the Deep Sea Drilling Project, Volume 16: Washington (U.S. Government Printing Office), p. 747-813.

Ehrenberg, C.G., 1874. Grössere Felsproben des Polycystinen-Mergels von Barbados mit weiteren Erläuterungen: Mber. Preuss. Akad. Wiss. Berlin, Jahrg. 1973, p. 213-263.

Foreman, H.P., 1968. Upper Maestrichtian radiolaria of California: Spec. Pa. Palaeontol., London (Palaeontology Association), no. 3, 82 p.

1973. Radiolaria of Leg 10 with systematics and ranges for the families Amphipyndacidae, Artotrobiidae, and Theoperidae. In Worzel, J.L., Bryant, W., et al., Initial Reports of the Deep Sea Drilling Project, Volume 10: Washington (U.S. Government Printing Office), p. $407-$ 474.

1975. Radiolaria from the North Pacific, Deep Sea Drilling Project, Leg 32. In Larson, R.L., Moberly, R., et al., Initial Reports of the Deep Sea Drilling Project, Volume 32: Washington (U.S. Government Printing Office), p. 579-676.

Haeckel, E., 1862. Die Radiolarien (Rhizopoda Radiolaria): Berlin (Reimer), xiv +572 p.; Atlas, iv p. +35 pl.

1879. Natürliche Schöpfungsgeschichte: Berlin (Reimer), 7th ed., 718 p., $17 \mathrm{pl}$.

1881. Entwurf eines Radiolarien-Systems auf Grund von Studien der Challenger-Radiolarien: Jena. Z. Med. Naturwiss., v. 15 (new ser., v. 8), p. 418-472.

1887. Report on the radiolaria collected by H.M.S. Challenger during the years 1873-76: Rept. Voyage Challenger, Zool., v. 18, clxxxviii + 1803 pp., 140 pls., I map.

Hays, J.D., 1965. Radiolaria and late Tertiary and Quaternary History of Antarctic Seas. In Biology of the 
Antarctic Seas II, Antarctic Research Ser. 5, Am. Geophys. Union, p. 125-184.

1970. Stratigraphy and evolutionary trends of Radiolaria in North Pacific deep-sea sediments: Geol. Soc. Am., Memoir 126, p. 185-218.

Johnson, D.A., 1974. Radiolaria from the eastern Indian Ocean, DSDP Leg 22. In von der Borch, C.C., Sclater, J.G., et al., Initial Reports of the Deep Sea Drilling Project, Volume 22: Washington (U.S. Government Printing Office), p. 521-575.

1976. Cenozoic radiolarians from the central Pacific, DSDP Leg 33. In Schlanger, S.O., Jackson, E.D., et al., Initial Reports of the Deep Sea Drilling Project, Volume 33: Washington (U.S. Government Printing Office), p. 425-437.

Johnson, D.A. and Knoll, A.H., 1975. Absolute ages of Quaternary radiolarian datum levels in the equatorial Pacific Ocean: Quaternary Res., v. 5, p. 99-110.

Kling, S., 1971. Radiolaria: Leg 6 of the Deep Sea Drilling Project. In Fischer, A.G., Heezen, B.C., et al., Initial Reports of the Deep Sea Drilling Project, Volume 6: Washington (U.S. Government Printing Office), p. 10691117.

1973. Radiolaria from the eastern North Pacific, Deep Sea Drilling Project, Leg 18. In Kulm, L.D., Von Huene, R., et al., Initial Reports of the Deep Sea Drilling Project, Volume 18: Washington (U.S. Government Printing Office), p. 617-671.

Moore, T.C., 1971. Radiolaria. In Tracey, J.I., Jr., Sutton, G.H., et al., Initial Reports of the Deep Sea Drilling Project, Volume 8: Washington (U.S. Government Printing Office), p. 727-775.

1972. Mid-Tertiary evolution of the radiolarian genus Calocycletta: Micropaleontology, v. 18, p. 144-152.

Nigrini, C.A., 1967. Radiolaria in pelagic sediments from the Indian and Atlantic Oceans: Scripps Inst. Oceanogr. Bull., v. 11 , p. $1-106$.

1971. Radiolarian zones in the Quaternary of the equatorial Pacific Ocean. In Funnell, B.M. and Riedel, W.R. (Eds.), The micropaleontology of oceans: (Cambridge University Press), p. 443-461.

19/4. Cenozoic radiolaria from the Arabian Sea, DSDP Leg 23. In Initial Reports of the Deep Sea Drilling Project, Volume 26: Washington (U.S. Government Printing Office), p. 1051-1121.

Petrushevskaya, M.G. and Kozlova, G.E., 1972. Radiolaria: Leg 14, Deep Sea Drilling Project. In Hayes, D.E., Pimm, A.C., et al., Initial Reports of the Deep Sea Drilling Project, Volume 14: Washington (U.S. Government Printing Office), p. 495-648.

Riedel, W.R., 1953. Mesozoic and Late Tertiary Radiolaria of Rotti. J. Paleont., v. 27, p. 805-813.

Riedel, W.R., 1954. The age of the sediment collected at Challenger Station 225, and the distribution of Ethmodiscus rex: Deep-Sea Res., v. 1, p. 170-175.

1957. Radiolaria: a preliminary stratigraphy: Rept. Swedish Deep-Sea Exped., v. 6, p. 61-96.

1959. Oligocene and lower Miocene Radiolaria in tropical Pacific sediments: Micropaleontology, v. 5, p. 285-302.

W.R., 1967a. Some new families of Radiolaria: Geol. Soc. London, Proc., no. 1640, p. 148-149.

1967b. Protozoa (Subclass Radiolaria). In Harland, W.B., et al. (Ed.), The fossil record, London (Geol. Soc. London), p. 291-298.

Riedel, W.R. and Sanfilippo, A., 1970. Radiolaria, Leg 4, Deep Sea Drilling Project. In Badar, R.G., Gerard, R.D., et al., Initial Reports of the Deep Sea Drilling Project; Volume 4, Washington (U.S. Government Printing Office), p. 503-575.
1971. Cenozoic Radiolaria from the western tropical Pacific, Leg 7. In Winterer, E.L., Riedel, W.R., et al., Initial Reports of the Deep Sea Drilling Project, Volume 7: Washington (U.S. Government Printing Office), p. 1529-1672.

1974. Stratigraphy and evolution of tropical Cenozoic radiolarians, Proc. III Planktonic Conference, Kiel (unpublished MS).

, in press. Cenozoic Radiolaria. In Ramsay, A.T.S. (Ed.), Oceanic Micropaleontology.

Sanfilippo, A., Burckle, L.H., Martini, E., and Riedel, W.R., 1973. Radiolarians, diatoms, silicoflagellates and calcareous nannofossils in the Mediterranean Neogene: Micropaleontology, v. 19, p. 205-234.

Sanfilippo, A. and Riedel, W.R., 1970. Post-Eocene 'closed' theoperid radiolarians: Micropaleontology, v. 16, p. 446462.

1973. Cenozoic Radiolaria (exclusive of theoperids, artostrobiids and amphypyndacids) from the Gulf of Mexico, Deep Sea Drilling Project, Leg 10. In Worzel, J.L., Bryant, W., et al., Initial Reports of the Deep Sea Drilling Project, Volume 10: Washington (U.S. Government Printing Office), p. 475-611.

1974. Radiolaria from the west central Indian Ocean and Arabian Sea, DSDP Leg 24. In Fisher, R.L., Bunce, E.T., et al., Initial Reports of the Deep Sea Drilling Project, Volume 24: Washington (U.S. Government Printing Office), p. 997-1035.

Wetzel, O., 1935. Radiolarien. In Wetzel, O. Die Mikropaläontologie des Heiligenhafener Kieseltones (OberEozän): Niedersächs. Geol. Vereins, Jahresber, v. 27, p. $48-74$.

\section{APPENDIX: PALEOGENE RADIOLARIA AT SITE 368}

Helen P. Foreman Oberlin College, Oberlin, Ohio

Because radiolarians are known to sometimes be preserved in porcellanite and chert when they are not preserved in the surrounding softer sediments, porcellanite samples were examined throughout the sequence between Cores 32 to 44 to determine if they contained Cretaceous radiolarians. However, instead of Cretaceous radiolarians, they were found to contain early Eocene-?late Paleocene radiolarians in varying degrees of preservation and abundances. Porcellanite samples yielded radiolarians as follows: Samples 32-5, 127-129 cm (VR, P, partly pyritized); 33-2, $24-25 \mathrm{~cm}$ (C, M); 34-1, 49$51 \mathrm{~cm}$ (F, M-G); 34-3, 94-96 cm (F, P); 35-1, 148-150 cm (F, P); 36-2, $128-130 \mathrm{~cm}$ (F, M-P); 37-4, 126-127 cm (F, M-P); 37-5, 135-137 cm (C, M-G);39-3, 56-57 cm (VR, P); 39-3, 56-57 cm (VR, P); 39-6, $115-$ $116 \mathrm{~cm}$ (F, M-G); 40-2, 48-50 cm (R, P); 40-3, 48-50 cm (F, M-P); 40$4,54-56 \mathrm{~cm}$ (F, M-P); 41-3, 113-115 cm (F, M-G); 41-4, 30-32 cm (F, M-G); 43-1, 100-102 cm (F, M-G); 43-2, 39-40 cm (F, M-G); 43-3, 48$50 \mathrm{~cm}(\mathrm{R}, \mathrm{M}) ; 43-4,49-50 \mathrm{~cm}(\mathrm{C}, \mathrm{G}) ; 44-2,8-11 \mathrm{~cm}(\mathrm{R}, \mathrm{P})$.

It seemed useful to investigate these radiolarians further and the resulting table of abundances (Table 4), made for selected species, accompanied by a list of the species, is presented here. In both the table and the list the taxa are arranged alphabetically by family and alphabetically by species within each family. This list does little more than give one or two references to a source where the species is fully described or synonymized, with occasional added notes representing explanations or new information. Three samples, 32-5, 127-129 cm; $34-3,94-96 \mathrm{~cm}$; and $44-2,8-11 \mathrm{~cm}$; all contain only rare poor Radiolaria. Absences from these samples have not been recorded as it could not be determined if these absences were only due to the sparseness and poor preservation of the fauna or if these absences represented actual evolutionary or ecological change.

Two plates illustrate some of the radiolarians to give a general view of the fauna and to indicate the rather remarkable state of preservation of the radiolarians recovered from the porcellanites. It is interesting to note that while delicate spines and surface features are frequently preserved, the interiors of small forms are consistently filled, so that no internal structures could be viewed. 
Diatoms are consistently present, even in the samples listed above as containing only rare, poor radiolarians. (See Plate 1, Figures 6, 7).

\section{TAXONOMIC LIST \\ Family ACANTHODESMIIDAE Haeckel, 1862, emend. Riedel, 1967b}

Remarks: Although this family is well represented in the material studied, constraints of time did not allow species to be tabulated. One form is illustrated (Plate 1, Figure 9).

\section{Family ACTINOMMIDAE Haeckel, 1862, emend. Riedel, 1967b}

Astrosphaerin sp. E Sanfilippo and Riedel, 1973, p. 488, pl. 6, fig. 36; pl. 23, fig. 1, (Plate 1, Figures 2, 3)

Astrosphaerin sp. F Sanfilippo and Riedel, 1973, p. 488, pl. 6, fig. 7 ,

8; pl. 23, fig. 2, (Plate 1, Figure 4)

Remarks: Reexamination of Leg 10 material extends the upward morphological range of this form into the lower Buryella clinata Zone.

Astropshaerin? (Plate 1, Figure 1)

\section{Subfamily SATURANLINAE Deflandre, 1953}

Saturnulus planetes Haeckel, in Hays, 1965, p. 167, pl. 1, fig. 5. (Plate 1, Figure 8)

Remarks: Specimens observed here agree well with the form illustrated by Hays. They differ from the species as originally described, Haeckel, 1879, p. 705 , fig. 3 , in having a bladed ring.

Family SPONGODISCIDAE Haeckel, 1862, emend. Riedel, 1967b

Amphicraspedum murrayanum Haeckel, in Sanfilippo and Riedel, 1973, p. 524, pl. 10, fig. 3-6; pl. 28, fig. 1. (Plate 1, Figure 5) Stylotrochus quadribrachiatus quadribrachiatus Sanfilippo and Riedel, 1973, p. 526, pl. 14, fig. 1, 2; pl. 31, fig. 1. (Plate 1, Figure 10)

\section{Family AMPHIPYNDACIDAE Riedel, 1967a}

Amphiternis sp. cf. (?) Stichomitra alamedaensis (Campbell and Clark) in Foreman, 1973, p. 430, pl. 7, fig. 18; pl. 9, fig. 1

Amphiternis clava (Ehrenberg) in Foreman, 1973, p. 430, pl. 7, fig. 16, 17; pl. 9, fig. 2; Fig. 7. (Plate 1, Figure 12)

\section{Family PTEROCORYIDAE Haeckel, 1881, emend. Riedel, 1967b}

Podocyrtis (Podocyrtis) papalis Riedel and Sanfilippo, 1970, p. 533, pl. 11, fig. 1.

\section{Family THEOPERIDAE Haeckel, 1881, emend. Riedel, 1967b}

Bekoma bidartensis Riedel and Sanfilippo, 1971, p. 1592, pl. 7, fig. 1, 2, 5-7. Foreman, 1973, p. 432, pl. 3, fig. 20, 21; pl. 10, fig. 6 .

Remarks: The nominal species of the $B$. bidartensis Zone is entirely lacking in this material. Instead another form undescribed, and identified as Bekoma (?) sp. is tabulated and illustrated (Plate 1, Figure 14). This form has a cephalis as is typical for Bekoma. The thorax is very finely porous with the pores tending to be vertically aligned. These pores extend in rows downward onto the feet, which are bladed, taper to a point and have not been observed to branch as is typical for the genus Bekoma.

Buryella clinata Foreman, 1973, p. 433, pl. 8, fig. 1-3; pl. 9, fig. 19.

Buryella tetradica Foreman, 1973, p. 433, pl. 8, fig. 4, 5; pl. 9, fig. 13, 14. (Plate 1, Figure 11)

Remarks: The rare forms observed here differ slightly in having a surface with pronounced longitudinal ridges on the third segment.
Cinclopyramis sp. (Plate 1, Figure 13)

Lamptonium fabaeforme chaunothorax Riedel and Sanfilippo, 1970, p. 524, pl. 5, fig. 8, 9. (Plate 2, Figure 3)

Remarks: The large pores here and for the species $L$. pennatum suggest that the evolutionary lineage may progress from a form such as L. pennatum (Plate 2, Figure 2) rather than from Lamptonium fabaeforme fabaeforme as previously indicated. The specimen illustrated here differs from earlier described forms in having a long, basally bladed horn.

Lamptonium fabaeforme fabaeforme (Krasheninnikov) in Riedel and Sanfilippo, 1970, p. 523, pl. 5, fig. 6. (Plate 2, Figure 5)

Lamptonium pennatum Foreman, 1973, p. 436, pl. 6, fig. 3-5; pl. 11, fig. 13. (Plate 2, Figures 1, 2)

Lithochyrtis archaea Riedel and Sanfilippo, 1970, p. 528, pl. 9, fig. 7. Foreman, 1973, p. 436, pl. 2, fig. 4, 5.

Lychnocanomma auxilla Foreman, 1973, p. 437, pl. 2, fig. 6; pl. 11, fig. 1, 2. (Plate 2, Figure 4)

Phormocyrtis cubensis (Riedel and Sanfilippo), 1971, p. 1594, pl. 7, fig. $10,11$.

Phormocyrtis striata exquisita (Kozlova) in Foreman, 1973, p. 438, pl. 7, fig. 1-4, 7, 8; pl. 12, fig. 5. (Plate 2, Figure 9)

Phormocyrtis striata striata Brandt in Wetzel, 1935, p. 55, pl. 9, fig. 12. Foreman, 1973, p. 438, pl. 7, fig. 5. 6, 9

Phormocyrtis turgida (Krasheninnikov) in Foreman, 1973, p. 438, pl. 7 , fig. 10 ; pl. 12 , fig. 6 .

Pterocodon (?) anteclinata Foreman, 1975, p. 621, pl. 9, fig. 32-34.

Pterocodon (?) tenellus Foreman, 1973, p. 439, pl. 5, fig. 7; pl. 12, fig. 4. (Plate 2, Figure 6)

Theocorys acroria Foreman, 1973, p. 439, pl. 5, fig. 11-13, pl. 12, fig. 2.

Theocorys anaclasta Riedel and Sanfilippo, 1970, p. 530, pl. 10, fig. 2,3 .

Remarks: Theocorys anaclasta was looked for but not found. Instead, a form resembling it, Theocorys $\mathrm{sp}$. aff. Theocorys anaclasta (Plate 2, Figures 12, 13), was found. This species differs from $T$. anaclasta in having a shorter thorax with larger pores and three (?) downward directed, slender ribs incorporated in the walls of the thorax and proximal abdomen. Distally, they begin to extend freely at the approximate point where the abdomen constricts. It is presented here as a second possibility for the ancestor of $T$. anaclasta which was originally suggested to be Theocorys acroria. However, no connecting forms have been observed.

Theocotyle (Theocotyle) cryptocephala (?) nigriniae Riedel and Sanfilippo, 1970, p. 525, pl. 6, fig. 5, 6. Foreman, 1973, p. 440, pl. 4 , fig. $1-5$; pl. 12, fig. 17. (Plate 2, Figure 15)

Theocotyle (Theocotylissa) auctor Foreman, 1973, p. 441, pl. 4, fig. 8-10; pl. 12, fig. 13. (Plate 2, Figure 14)

Theocotyle (Theocotylissa) ficus (Ehrenberg) in Foreman, 1973, p. 441 , pl. 4 , fig. 16-20.

Theocotyle (Theocotylissa) fimbria Foreman, 1973, p. 441, pl. 5, fig. 1, 2; pl. 12, fig. 21. (Plate 2, Figure 11)

Remarks: The very rare specimens observed here all had only three teeth on the apertural rim.

Pterocodon (?) ampla (Brandt) in Wetzel, 1935, p. 56, pl. 9, fig. 1315. (Plate 2, Figure 8)

Remarks: The specimens observed here agree well with the original description by Brandt. They differ only in having a shorter horn. In one sample only, 368-43-4, 49-50 cm, smaller forms (Plate 2, Figure 7) identical to those described and illustrated in Foreman, 1973 , p. 439 , pl. 5 , fig. 3 , were observed.

Thyrsocyrtis hirsuta hirsuta (Krasheninnikov) in Riedel and Sanfilippo, 1970, p. 526, pl. 7, fig. 8, 9. Foreman, 1973, p. 441, pl. 3 , fig. $3-8$; pl. 12 , fig. 15 .

Thyrsocyrtis hirsuta tensa Foreman, 1973, p. 442, pl. 3, fig. 13-16; pl. 12 , fig. 8 .

\section{Incertae sedis}

Lophocyrtis biaurita (Ehrenberg) in Foreman, 1973, p. 442, pl. 8, fig. 23-26. 



\section{PLATE 1}

Figure $1 \quad$ Astrosphaerin ?; Sample 368-37-5, 135-137 cm; Sl. 4, E49/1; 133X.

Figures 2, $3 \quad$ Astrosphaerin sp. E.

2. Sample $368-43-3,49-50 \mathrm{~cm}$; Cs. 1 , V43/4; $133 \times$.

3. Sample $368-43-2,39-40 \mathrm{~cm}$; Sl. 3, H39/4; $133 \times$

Figure $4 \quad$ Astrosphaerin sp. F; Sample 368-39-6, 115-116 cm; Cs. 1, D35/0; 133×.

Figure 5 Amphicraspedum.murrayanum; Sample 368-43-4, $48-50 \mathrm{~cm} ; \mathrm{Sl} .4$; H24/0; $133 \times$.

Figures 6, 7 Diatoms; Sample 368-43-2, 39-40 cm; Sl. 2, U22/3; $214 \times$.

Figure 8 Saturnulus planetes; Sample $368-43-2,39-40 \mathrm{~cm}$; Sl. 2, G24/0; 133X.

Figure 9 Acanthodesmiid; Sample 368-39-6, 115-116 cm; Fn. 2, L16/0; 214X.

Figure 10 Stylotrochus quadribrachiatus quadribrachiatus; Sample 368-33-2, 24-25 cm; S1. 3, K25/0; 133×.

Figure $11 \quad$ Buryella tetradica; Sample 368-43-4, 49-50 cm; Fn. $2 ; 214 \times$.

Figure 12 Amphiternis clava; Sample 368-39-6, 115-116 cm; Fn. 2, V34/2; 214×.

Figure $13 \quad$ Cinclopyramis sp.; Sample 368-43-2, 39-40 cm; Sl. 3, U22/0; 214X.

Figure 14 Bekoma (?) sp.; Sample 368-43-4, 49-50 cm; Sl. 4, J32/4; 214X. 
PLATE 1
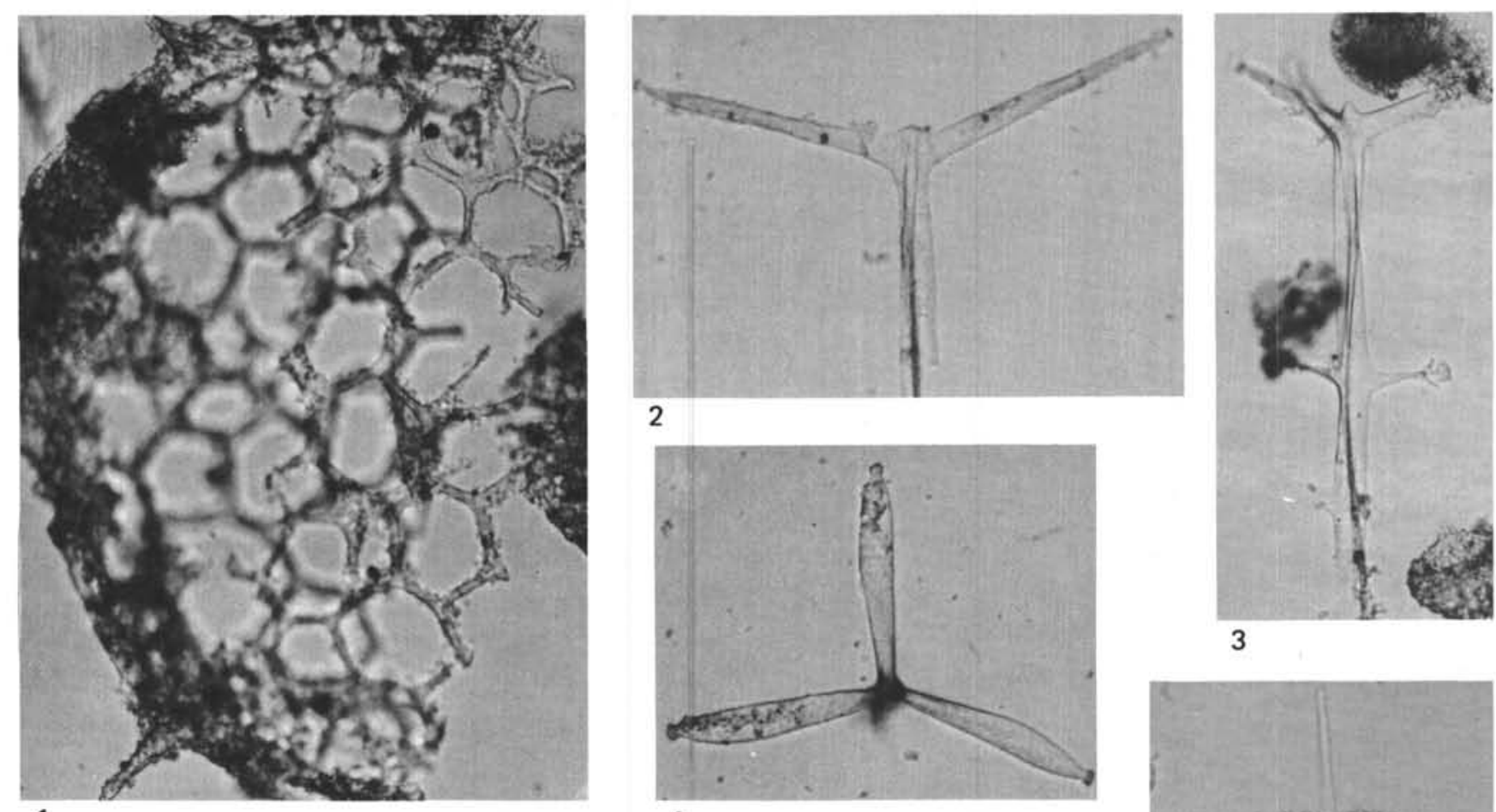

1
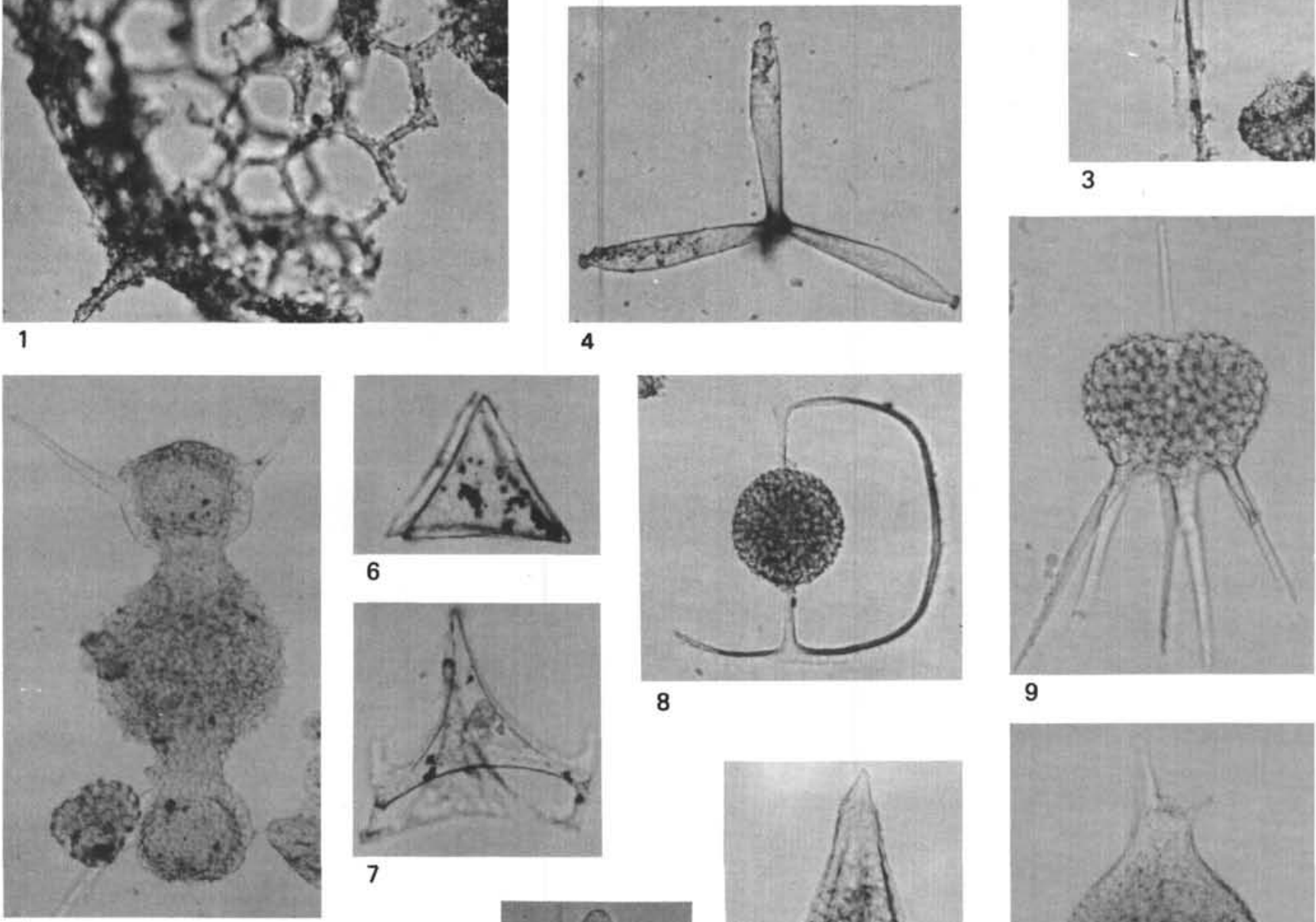

5
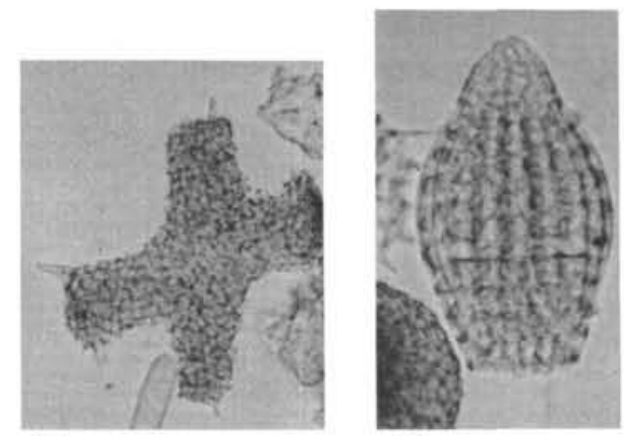

11
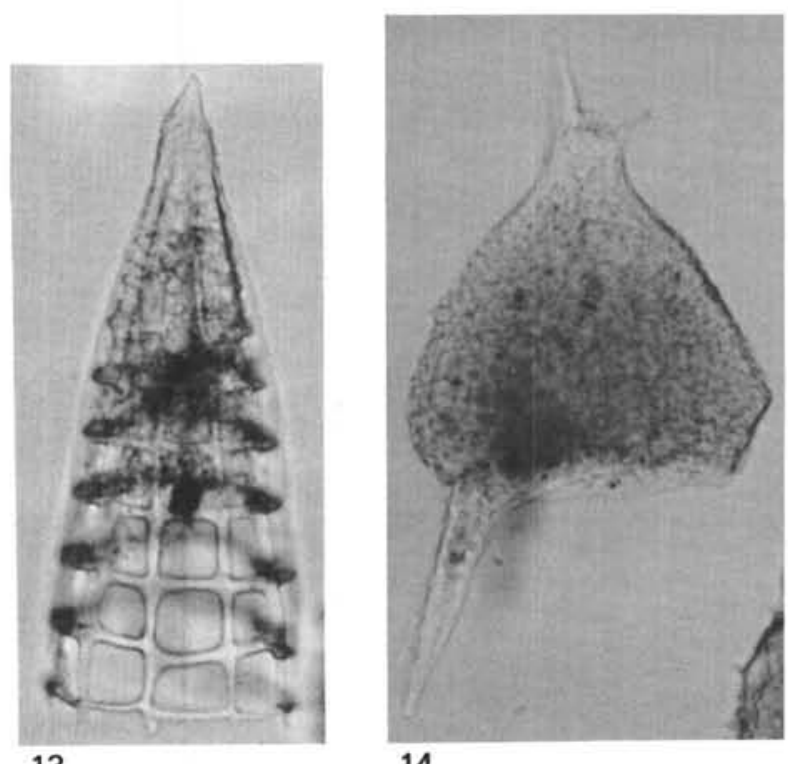


\section{PLATE 2}

All figures magnified $214 \times$

Figures 1,2 Lamptonium pennatum.

1. Sample $368-43-4,49-50 \mathrm{~cm}$; Fn. 2, T33/1.

2. Sample $368-43-2,39-40 \mathrm{~cm} ; \mathrm{Sl} .2, \mathrm{~T} 27 / 1$.

Figure 3 Lamptonium fabaeforme chaunothorax; Sample $368-37-5,135-137 \mathrm{~cm}$; Sl. 3, C36/4.

Figure $4 \quad$ Lychnocanomma auxilla; Sample 368-43-3, 39-40 cm; Sl. 2, M39/0.

Figure $5 \quad$ Lamptonium fabaeforme fabaeforme; Sample 36843-2, 39-40 cm; Sl. 3, S34/2.

Figure 6 Ptercodon (?) tenellus; Sample 368-39-6, 115-116 $\mathrm{cm}$; S1. 1, S34/1.

Figure $7 \quad$ Pterocodon (?) ampla (?); Sample 368-43-4, 49-50 cm; Fn. 2, B32/1.

Figure $8 \quad$ Pterocodon (?) ampla; Sample 368-39-6, 115-116 cm; Fn. 2.

Figure 9 Phormocyrtis striata exquisita; Sample 368-39-6, 115-116 cm; Sl. 1, Q36/1.

Figure 10 Thyrsocyrtis hirsuta hirsuta; Sample 368-41-3, 113$115 \mathrm{~cm}$; S1. 3, P29/4.

Figure 11 Theocotyle (Theocotylissa) fimbria; Sample 368-375, 135-137 cm; Sl. 5, L26/3.

Figures 12,13 Theocorys sp. aff. Theocorys anaclasta; Same specimen viewed from two opposite sides. Sample $368-43-2,39-40 \mathrm{~cm}$; Sl. 2, U19/2.

12. Shows thoracic and abdominal pores.

13. Shows two downward directed spines.

Figure 14 Theocotyle (Theocotylissa) auctor; Sample 368-432, 39-40 cm; Sl. 1, K37/0.

Figure 15 Theocotyle (Theocotyle) cryptocephala nigriniae; Sample 368-39-6, 115-116 cm; Fn. 2, D40/1. 


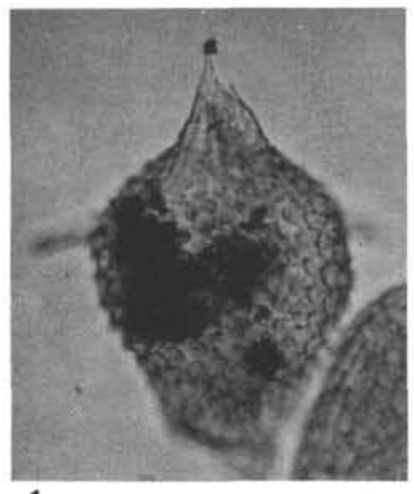

1

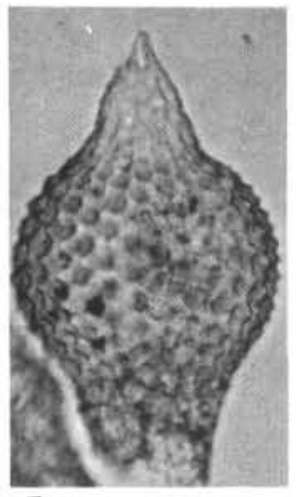

5
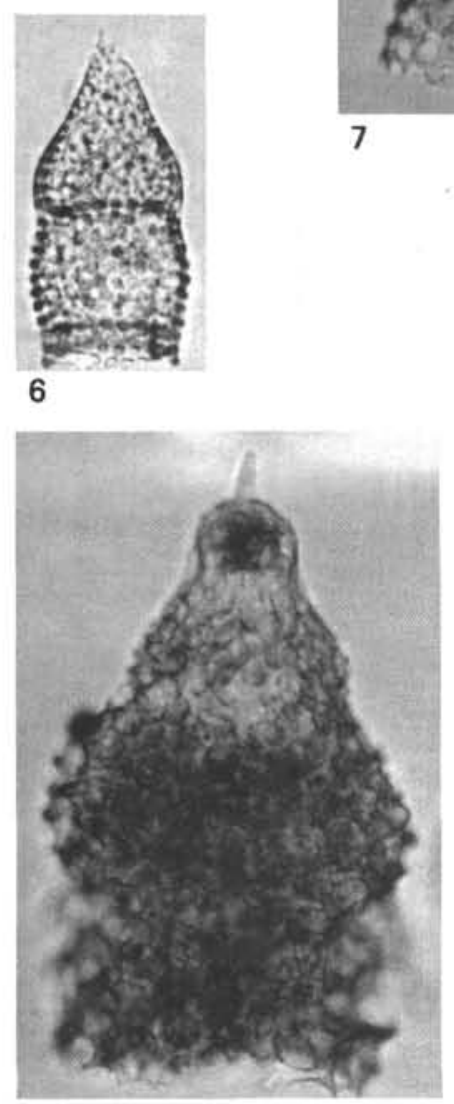

12
PLATE 2
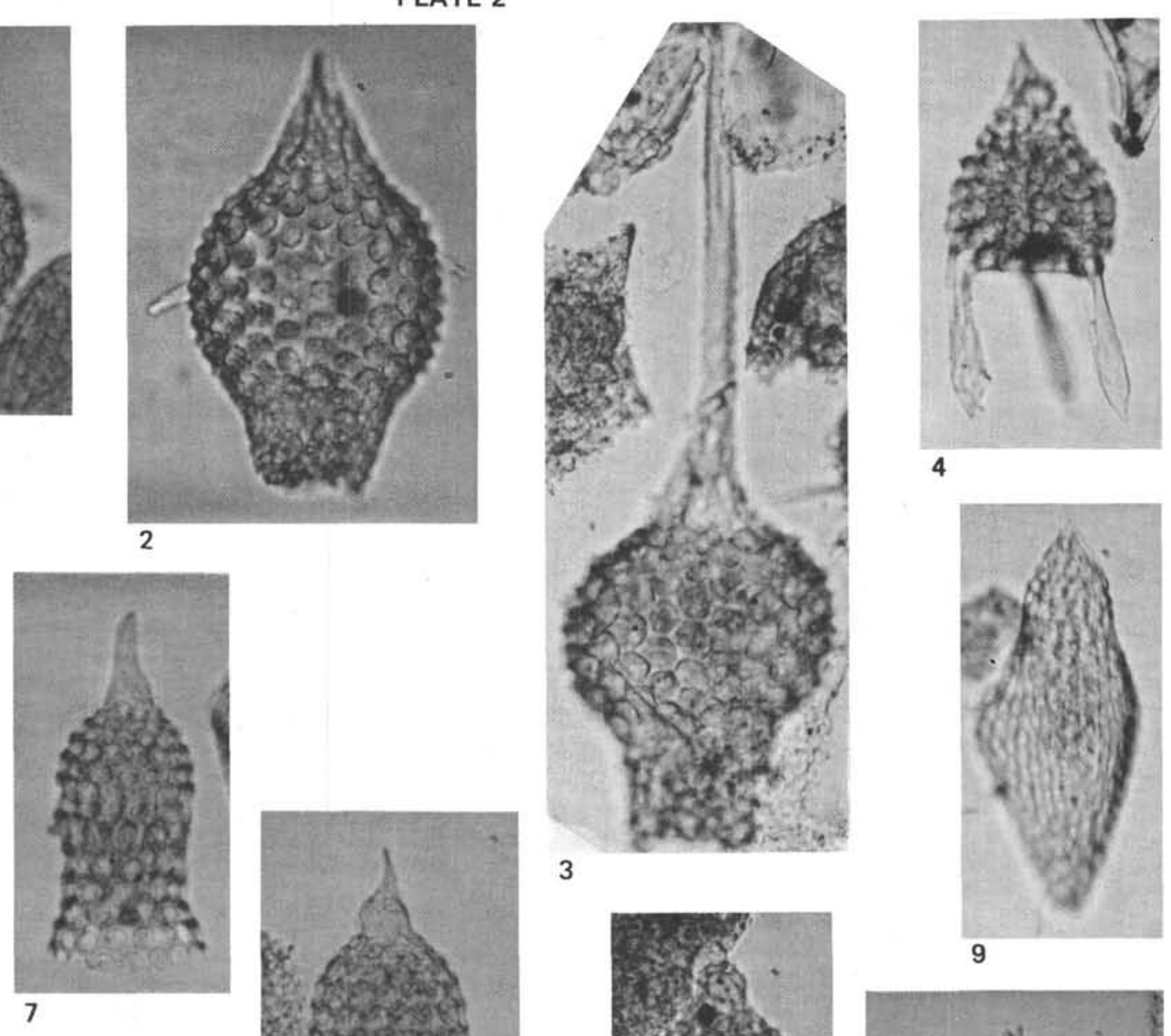

4
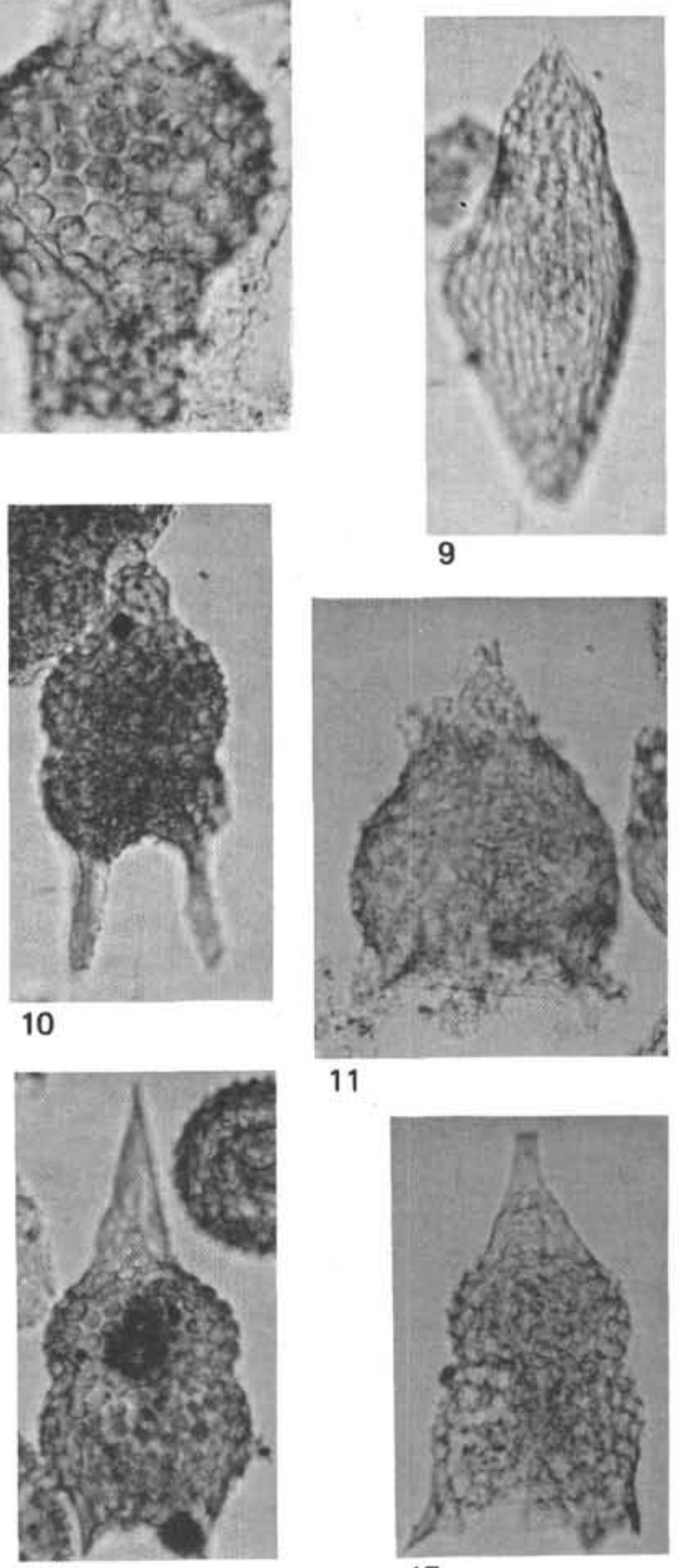

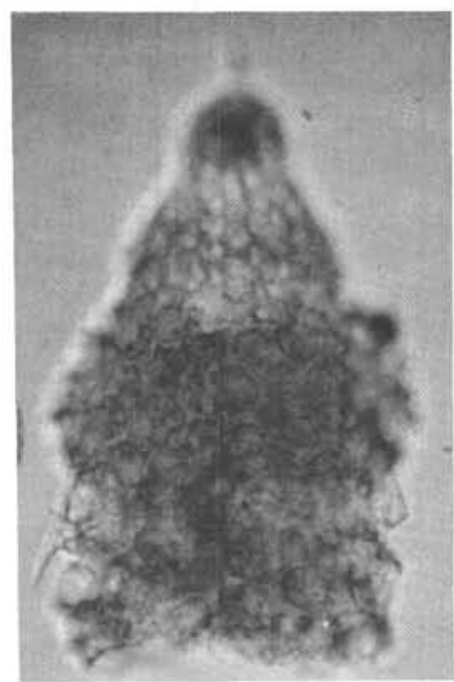

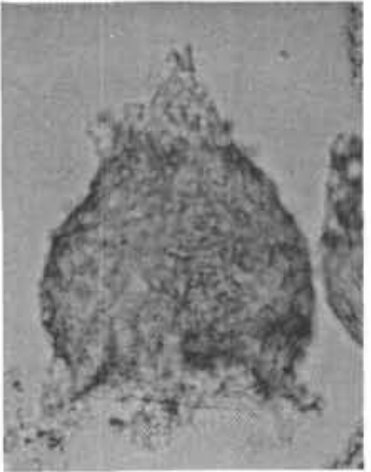

11

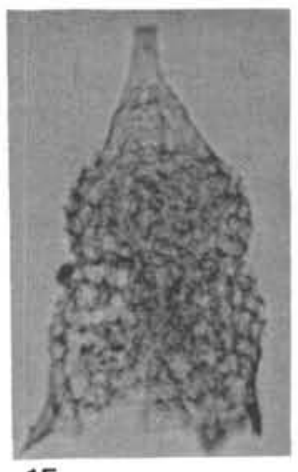

15 